Review/Praca poglądowa

\title{
Recommendations for the diagnosis of human papilloma virus (HPV) high and low risk in the prevention and treatment of diseases of the oral cavity, pharynx and larynx. Guide of experts PTORL and KIDL
}

\section{Rekomendacje dotyczące diagnostyki wirusów brodawczaka ludzkiego (HPV) wysokiego (HR) i niskiego ryzyka (LR) w profilaktyce i leczeniu chorób jamy ustnej, gardła i krtani. Stanowisko ekspertów PTORL i KIDL}

Małgorzata Wierzbicka ${ }^{1,2, *}$, Agata Józefiak ${ }^{3,4}$, Jarosław Szydłowski ${ }^{5}$, Andrzej Marszałek ${ }^{6}$, Czesław Stankiewicz ${ }^{1}$, Elżbieta Hassman-Poznańska ${ }^{1}$, Ewa Osuch-Wójcikiewicz ${ }^{1}$, Jacek Składzień ${ }^{1}$, Janusz Klatka ${ }^{1}$, Wioletta Pietruszewska ${ }^{1}$, Elżbieta Puacz ${ }^{3}$, Krzysztof Szyfter ${ }^{2,7}$, Witold Szyfter ${ }^{1,2}$

\footnotetext{
${ }^{1}$ Polskie Towarzystwo Otolaryngologów Chirurgów Głowy i Szyi, Gdańsk, Poland

${ }^{2}$ Klinika Otolaryngologii i Onkologii Laryngologicznej UM w Poznaniu, Ordynator: prof. $d r$ hab. med. Witold Szyfter, Poland

${ }^{3}$ Krajowa Izba Diagnostów Laboratoryjnych, Warszawa, Poland

${ }^{4}$ Klinika Otolaryngologii Dziecięcej UM w Poznaniu, Kierownik: prof.dr hab.med. Michał Grzegorowski, Poland

${ }^{5}$ Katedra Fizjologii i Biochemii Zwierząt, Uniwersytet Przyrodniczy w Poznaniu, Kierownik: prof. dr hab. Paweł Maćkowiak, Poland

${ }^{6}$ Katedra i Zakład Patomorfologii Klinicznej, Collegium Medicum w Bydgoszczy, Uniwersytet im. M. Kopernika w Toruniu, p.o. Kierownika: dr hab. n. med. Andrzej Marszałek, prof. UMK, Poland

${ }^{7}$ Instytut Genetyki Człowieka PAN w Poznaniu, Kierownik: prof. dr hab. Maciej Kupisz, Poland
}

A R T I C L E I N F O

Article history:

Received: 11.12 .2012

Accepted: 09.01.2013

Available online: 11.01 .2013

Keywords:

- HPV

- Prevalence

- Head and neck cancer

- Recurrent laryngeal

papillomatosis

- Detection
A B S T R A C T

The role of human papilloma viruses (HPV) in malignant and nonmalignant ENT diseases and the corresponding epidemiological burden has been widely described. International head and neck oncology community discussed growing evidence that oral HPV infection contributes to the risk of oro-pharyngeal carcinoma (OPC) and recommended HPV testing as a part of the work up for patients with OPC.

Polish Society of ENT Head Neck Surgery and National Chamber of Laboratory Diagnosticians have worked together to define the minimum requirements for assigning a diagnosis of HPV-related conditions and testing strategy that include HPV specific tests in our country. This paper briefly frames the literature information concerning low risk (LR) and high risk (HR) HPV, reviews the epidemiology, general guidance on the most appropriate biomarkers for clinical assessment of HPV. The definition of HPV-related cancer was presented. The article is aiming to highlight some of major issues for the

\footnotetext{
* Corresponding author: Klinika Otolaryngologii i Onkologii Laryngologicznej UM w Poznaniu, ul. Przybyszewskiego 49, 60-355 Poznań. Tel.: 61869 1387; fax: 618691690.

E-mail address: gowierzb@yahoo.co.uk (M. Wierzbicka). 0030-6657/\$ - see front matter ๑ 2013 Polish Otorhinolaryngology - Head and Neck Surgery Society. Published by Elsevier Urban \& Partner Sp. z o.o. All rights reserved. http://dx.doi.org/10.1016/j.otpol.2013.01.003
} 
- Molecular diagnosis

- Screening

- Recommendations

Słowa kluczowe:

- HPV

- rozpowszechnienie

- rak głowy i szyi

- nawracająca papillomatosis krtani

- wykrywanie

- diagnostyka molekularna

- badania przesiewowe

- zalecenia clinician dealing with patients with HPV-related morbidities and to introduce the diagnostic algorithm in Poland.

( 2013 Polish Otorhinolaryngology - Head and Neck Surgery Society. Published by Elsevier Urban \& Partner Sp. $\mathrm{z}$ o.o. All rights reserved.

\section{Introduction}

The role of human papilloma viruses (HPV) in the pathogenesis of diseases of the oral cavity, throat, larynx and maxillo-ethmoid complex

So far, 200 various types of HPV (human papillomavirus) have been identified. This group can be divided into the following classes: $\alpha, \beta, \gamma, \mathrm{Mu}$ and $\mathrm{Nu}$. Some of the viral genotypes mentioned above are sexually transmitted. Due to their varied oncogenic potential the following types can be distinguished: high risk (HR) HPV, i.e. HPV 16, HPV 18, HPV 31, HPV 33 and HPV 45, associated with more than $80 \%$ of cervical cancers and low risk (LR) HPV, i.e. HPV 6 and HPV 11 associated with mild intraepithelial low-grade lesions or laryngeal papillomas. Viruses from the $\beta$ group infect the skin, whereas the remaining types ( $\gamma, \mathrm{Mu}$ and $\mathrm{Nu}$ groups) are responsible for the formation of papillomas that usually are not subject to neoplastic transformation [1].

Infections with HR HPV are responsible for 600,000 cases of cancer of the cervix, vulva, vagina, anus, oral cavity and oropharynx diagnosed annually on the whole world. Moreover, they are causative factors for condylomas and recurrent papillomas of the respiratory system. The incidence of cervical cancer has been declining for many decades, but the incidence of anal cancer as well as head and neck cancers has been a growing problem. Consequently, an interdisciplinary research programme Eurogin 2011 [2] on the prevention and treatment of HPV-dependent diseases has been established in order to discuss the problems of morbidity, registers and diagnostic and therapeutic recommendations.

\section{Head and neck cancers}

Head and neck squamous cell carcinomas (HNSCC) originate from the squamous epithelium lining the upper respiratory tract and the upper gastrointestinal tract. It is a heterogeneous group of cancers developing in different primary locations, with common risk factors and similar pathology. Their aetiology is multifactorial, and development consists of multistage cancerogenesis preceded by dysplastic lesions of the mucous membrane. In accordance with the ICD-10 classification [3] there are the following primary locations for HNSCC: tongue (C01.9-C02.9); gum (C03.0-C03.9); bottom of the oral cavity (C04.0-C04.9); palate (C05.0-C05.9); other locations in the oral cavity (C06.0C06.9); tonsils (C09.0-C09.9); oropharynx (C10.0-C10.9); laropharynx (C12.9, C13.0-C13.9); other locations in the pharynx (C14.0, C14.2-C14.8); larynx (C32.0-C32.9).

\section{The role of HPV in the development of HNSCC}

Within recent decades epidemiological and molecular studies have indicated that human papilloma viruses play a role in the development of some subsets of HNSCC. The contribution of HPV in the cancerogenesis of cancers of the oral cavity and oropharynx was for the first time suggested by zur Hausen in 1999 [4] and Syrjanen in 2005 [5], then confirmed by research groups of Erdmann [6], Nair [7] and Gillison [8] based on the following observations: HPV tropism towards epithelial cells, changes in the genome of human keratinocytes in in vitro studies, widely documented oncogenic potential of HR HPV subtypes in the development of cervical cancer and morphological similarities between the epithelium of the oral cavity and throat, and the epithelium of the genitourinary tract. HPV DNA in precancers and invasive carcinoma of the oral cavity is observed three and five times more frequently, respectively, when compared to healthy mucous membrane [5, 9]. A HR HPV infection is observed in $25 \%$ of oral cavity cancers, and HPV 16 is observed in $70 \%$ of HPV-positive cancer tissue specimens; in the case of oropharyngeal cancers these values are higher, namely $35 \%$ and $90 \%$, respectively $[8,10$, 11]. HPV 16 increases the risk for HNSCC four times.

Different primary locations have different significance with regard to predilection for developing and prevalence of HR HPV in HNSCC: it significantly more often occurs in the oropharynx in comparison with the oral cavity and larynx [5, 12-17]. The presence of HR HPV in cancer tissue has become the basis to distinguish a separate subset of HNSCC: HPV-associated cancers.

HPV-associated cancers have different biological parameters which are associated with a profile of gene expression, frequency of the TP53 mutation and the p16 expression. They are poorly differentiated in a histological examination [18]. The mean age of patients with HPV-associated cancers is significantly lower and the contribution of addictions that are considered to be classical risk factors, namely smoking 
and alcohol abuse is significantly lower or negative; and sexual habits are different: a higher number of sexual partners and oral sex. An association between a tumour and HPV 16 is a documented prognostic factor: locoregionally advanced pharyngeal cancers have a $60 \%$ lower risk of mortality and a $30 \%$ better 5-year survival rate [19-21]. A difference in 5-year overall survival rates is a resultant of many factors: younger age, better general condition, lower burden, a higher response rate to radio and chemotherapy, and a lower risk of second primary cancer. Smoking more than 10 cigarettes daily reduces favourable chances of survival for patients with HPV-associated HNSCC [17, 22-25]. Despite more aggressive metastases to the cervical lymphatic system the prognosis is still better than for HPVindependent cancers [26].

The role of LR HPV is still controversial. HPV 6 and 11 types are observed in a low percentage of HNSCC, but they are not considered to be "completely mild" in the region of the head and neck [27]. It has been proven that mild papillomas with HPV 6 and 11 aetiology are subject to malignant transformation following irradiation. This observation is confirmed by an aggressive course observed for papillary cancers of the urinary tract. LR HPV is observed in $25 \%$ of HNSCC and this group has poorer outcomes of treatment including radiochemotherapy. A LR HPV coinfection has to be studied further and such studies may in the future be a reason for changing a treatment strategy (radiation therapy replaced by surgery).

\section{The incidence of HPV-associated HNSCC}

In Europe the incidence of HPV-associated HNSCC ranges from $20 \%$ in the Netherlands to $41 \%$ in Switzerland, $55 \%$ in Germany and $62 \%$ in France. In the USA the rates are higher, $64 \%$ to $72 \%$. Discrepancies in these results stem from the following: (1) differences in the ethnicity and geographical regions, (2) different sensitivity of diagnostic methods used (varied materials: biopsy, scrapings, smears, brush smears, biopsy specimens), (3) different methods to store and process material (fresh, frozen, formalin-fixed paraffinembedded specimens), (4) methods to detect HPV [28, 29].

Since the 1980s the incidence of HNSCC has gradually decreased, in particular in the USA, what is related with the limitation of classic risk factors such as tobacco smoking and alcohol abuse. Along with this tendency it is possible to observe varied numbers of cases depending on the association between HNSCC and HPV. The acute peak of the incidence of HPV-associated HNSCC is observed worldwide, in Europe this peak is higher than in the USA [30]. A significant increase in the number of cases has been observed for primary locations with a high rate of HPVassociated cancers: cancers of the tonsils and base of the tongue with a parallel increase in HPV infections within the oral cavity and the throat $[13,31-35]$. At the same time, in $\mathrm{HPV}$-associated locations there is an increased incidence of cancers in lower-age groups (45-54) in comparison with older cohorts. The increase in the number of cases is the highest among men aged 40-64 years. It can be partially explained by the frequency of HR HPV infections of the genital organs: in the healthy population 29-65\% among men and $25 \%$ among women. The incidence of oral cavity infections is $10 \%$ and $3.6 \%$, respectively. Moreover, there are immunological differences between sexes, and there is a higher number of sexual partners among men [36-38].

\section{Risk factors for HPV-associated HNSCC}

The reasons accounting for the increase in the number of HPV-associated cancer cases are not clear; however, they seem to be associated with the fact that sexual habits have changed. An HPV infection of the oral cavity is associated with a 4- to 12-times increased risk of HNSCC development. The following have been proven: (1) a direct relation between a viral infection of the genital organs and the presence of an HPV infection in the oral cavity, (2) a lowered age of sexual initiation, (3) a high number of sexual partners, (4) lack of condom use, (5) oral sex. Open mouth kissing is also a source and a favouring factor of viral transmission. Higher rates of tonsil cancers have been observed in partners of women with cervical cancer. Synchronous cancers of the oral cavity have been confirmed in partners infected with the same HPV subtype [25, 39-41]. There have been no long-term studies on HPV transmission among sexual partners. A higher risk of an HPV infection has been confirmed in people with post-transplantation immunosuppresion and HIV-infected.

\section{HPV infections specific for individual primary locations of HNSCC}

Precancerous conditions of the oral cavity

The presence of HPV DNA in precancerous lesions of the oral cavity and throat is estimated to be wide, $0-85 \%$, with predominant HPV 16 and 18 genotypes [42]. Miller 2012 and White 2012 [43, 44] identified HPV in 43\% of fresh or frozen specimens, and in $12 \%$ of paraffin-embedded specimens from lesions that were clinically assessed as leukoplakia, but without dysplasia in a pathological examination. Verrucous leukoplakia is definitely more potently related to HPV, and it is a rare and aggressive form of proliferative leukoplakia with a high $(90 \%)$ risk of malignant transformation, treatment-resistant and mainly developing in elderly women. Its aetiology is not associated with cigarette smoking or a fungal infection, and HPV 16 was confirmed in $25.5-80 \%$ of cases. On the other hand, in lichen planus the contribution of a viral infection has not been unambiguously confirmed, with the exception of cases with a clinical presentation including ulcerations that have been linked to the HPV 18 genotype [42, 45].

\section{Oropharyngeal cancers (OPCs)}

The number of OPC cases worldwide is 137,000 cases, and the number of deaths reaches 96,000 annually; 61,500 cancers origin from anatomical areas where cancerogenesis has been documented to be causally linked with HPV (palatal tonsils, base of the tongue).

The HPV distribution in patients with OPCs has been estimated to be in a wide range of $5-70 \%$ [9]. The last metaanalysis [30] indicated that until 2000 the share of HPV infections was 41\%, until $2004-72 \%$ and after 2004 there 
was an increase up to $96 \%$. The presence of HPV in OPCs is higher in the USA $(60 \%)$ than in Europe $(40 \%$, EUROCARE project) and other parts of the world (33\%). Increasing tendencies in the number of OPC cases and an increased incidence of HPV infections have been confirmed by all researchers, regardless of the studied population and applied methodology. In the USA the number of HPVassociated cases has increased by $225 \%$ and of those not associated with HPV has decreased by 50\% [46].

Within the last two decades HPV as the main causative factor of cancerogenesis has replaced cigarette smoking and alcohol abuse. HPV virulence as well as long-term consequences of this infection have been emphasised: the total risk of OPC development in patients with alcohol problem is 5.5 , in those with smoking addiction 19.5, and in the case of synergistic effects of both addictions 56.5, whereas it is 230.0 in the case of an HPV infection [47]. The majority of HPVassociated OPCs is associated only with HPV 16 (84-87\% of palatal tonsil cancers). The remaining types 18, 33, 35 are responsible for a small number of cases. Approximately $3 \%$ of cancers can be caused by an infection with LR HPV: 6 and 11 .

The effects of an HPV infection on the prognosis in OPC has been documented. Risk reduction for HPV-associated cancers was $15 \%$, and the risk of death was lower by $38 \%$ [48]. The ECOG (European Cooperation Oncology Group) phase II protocol and TROG 02.02 and phase III TAX have unanimously indicated that HPV in this location is associated with a significantly better prognosis [49]. With regard to HPV-associated OPCs with class III/IV organ involvement ECOG has completed recruitment of patients for phase II trials on deintensification of radiochemotherapy. Reports on the outcomes of TORS surgery for HPV-associated and independent cancers have not yet been finally known.

\section{Oral cavity cancers}

The role of HPV in the cancerogenesis of oral cavity cancers remains controversial. The meta-analysis of Syrjanen [50] has indicated a quadruple increase in the risk of oral cavity cancers in patients with an HPV 16 infection; however, the risk level estimated with this method turned out to be identical as in the case of malignant transformation of precancerous conditions. The analysis by Ribeiro [51] has not confirmed a statistically significant relationship between an HPV infection and oral cavity cancers. The most common type of HPV identified in oral cavity cancers is HPV 16; only reports from the South Africa [52] have indicated the role of only HPV 18 , whereas the coincidence of both subtypes is common [53]. Types that are detected more rarely include HPV 8, HPV 31, HPV 38, HPV 66 [54]. LR HPV which is also rarely detected is a bystander and not driver of cancerogenesis.

HPV DNA is observed in $25 \%$ of oral cavity cancers. HR HPV E6/E7 RNA is present in $85 \%$ of HPV-associated cancers and in $33.7 \%$ of all cancers of this location. When HPV is confronted with classic risk factors it can be seen that cigarette smoking is more significant (the risk of cancer in smokers and alcohol consumers is significantly higher than in seropositive patients) [16]. There is also no evidence to support a better prognosis in HPV-associated cancers [55]; it is the only tendency without statistical significance [53]. The primary location discussed above has to be studied further in order to define accurately the role of HPV as a potential causative and prognostic factor.

Laryngeal cancers

HPV DNA is detected in approx. 9.6\% of normal larynxes. The HPV rate observed in cancers of this organ is slightly higher (up to 23\%). HPV 16 is the most frequently detected viral type in laryngeal cancers; however, the highest differentiation of types was observed for HNSCC in this location: HPV 18, 26, 31, 33, 39, 36, 45, 51,52, 58, 59, 66 and 69 [56-58]. No demographical differences were observed. The HPV transcriptional activity was reported in only few cases, although the number of viral copies in tumours was significantly higher when compared to non-malignant lesions. It supports the theory of a "driving" role of HPV in this anatomical location [59]. No effects of HPV on the prognosis in laryngeal cancers were observed [60]. This virus is thought to be one of cancerogenesis promoters; however, it is not an independent, isolated causative factor.

\section{Tumours of the maxillo-ethmoid complex}

Data regarding asymptomatic carriers of HPV in the nasal cavity are scarce, and in polyps this virus is present in nearly $3 \%$ of cases [61]. An aetiological relationship between HPV and inverted papillomas (IP) has been documented; viral DNA is detected in approx. $25 \%$ of tumours. The HPV rate significantly increases in IP with high grade dysplasia and IP with neoplastic cancer. In the aetiology of mild IPs the role of LR HPV has been confirmed, and a thesis has been suggested that HR HPV is responsible for transformation into malignant cancers and their rapid progression [62].

Reports on the role of HPV in tumours of the maxilloethmoid complex are rare, and based on small, heterogeneous research groups, and take into account different tumour tissues. HPV DNA is observed in approx. $21-30 \%$ of cancers, and HPV 16 is the most detected type. Final conclusions regarding the effects of HPV on the clinical course and prognosis cannot be made due to insufficient experience collected so far [63].

\section{Salivary gland tumours}

Literature reports on the role of HPV in the development of salivary gland tumours are scarce, and based on small groups (up to 20 patients); in addition, the study results are inconsistent. It has been detected that HR HPV is a cancerogenesis promoting factor in mucous-epithelial cancers the incidence of which has been on the increase within the last two decades [64]. The presence of HPV DNA has also been observed in Warthin tumours, polymorphic adenomas, lobular cancer [65], and the highest rate was observed in cysticglandular cancers [66]. The significance of HPV in the development of salivary gland tumours has not yet been proven finally; nonetheless, recent reports are sceptical [67].

\section{The screening programme and prevention of HPV-associated cancers}

Current screening programmes are aimed to detect lesions early, and consequently to limit the incidence and mortality due to cancers. The countries that have introduced cytologi- 
cal screening have managed to significantly limit the incidence and mortality rates in women due to cervical cancer. An infection with oncogenic types of human papillomavirus is a factor necessary for the initiation and progression of dysplastic lesions in the cervix. It has been demonstrated that cytology screening tests combined with HPV diagnostics are more sensitive with regard to detection of cervical intraepithelial neoplasia (CIN) when compared to cytology screening tests alone. When a precancerous condition is detected appropriately early it is possible to introduce effective, cheap and fast treatment in order to achieve treatment success of almost $100 \%$.

As a response to a sudden and unexplained increase in the number of HPV-associated HNSCC cases in 2011 there was an attempt to design first screening tests similar to cytology screening tests for cervical cancer. It was proven [68] that in exfoliative cytology specimens of the oral cavity an HPV infection was observed significantly more rarely in the control group when compared to patients with cancer. Moreover, there is clinical evidence that HPV DNA obtained in a brush smear indicates a higher risk of cancer or a local relapse after the treatment has been completed [69]. In a screening study [70] two groups of patients were compared: those reporting due to complaints in the throat and HIV-infected patients in whom the risk of tonsil cancer is two to six times higher than in a general population; however, no relationship between an HPV 16 infection and atypical manifestation of squamous epithelial cells or signs of dysplasia was observed, consequently, the screening study was assessed negatively.

Currently, there are no simple and reliable tools to attempt screening tests for an HPV infection of the oral cavity and oropharynx. There have been no commonly approved screening tests for precancerous conditions of the oral cavity [39]. In the United Kingdom, as a result of the introduction of a routine HPV test using a PCR method as part of a screening programme the prices of tests decreased, and currently, their costs are a fraction of all costs associated with the whole oncological programme; nonetheless, there is no evidence to support the cost-efficacy of such proceedings [71].

The significance of vaccination with a quadrivalent HPV vaccine has been well-known as part of prophylaxis for cervical cancer in women. However, there are no data on how to prevent transmission and expression of oncogenic HPV of the oral cavity, although there are reasons to believe that vaccinations in this field might be potentially effective [72]. In the USA vaccination for HPV 16, 18 in boys has been considered; however, based on an initial analysis it cannot be justified when the whole population of women is subject to vaccination and the cost-efficacy is not sufficient [73]. The problem of vaccination as a prophylactic measure for OPCs is still an open question and multicentre trials are necessary.

\section{Recurrent respiratory papillomatosis (RRP)}

RRP in children is the most common non-malignant disease of the respiratory tract in this age group. It is thought that each interaction of the human papillomavirus with a susceptible cell may result in infection [74, 75]. When diagnostic capabilities are considered as a criterion of classification the following three basic types of infection can be distinguished [75, 76]: clinical (apparent) - the presence of macroscopically visible flat or exophytic, sometimes balloting papillomatous formations; subclinical - visible only during a histological examination; latent (dormant) - there are no visible macroscopic or microscopic lesions, and the appropriate diagnosis can be made only based on the results of molecular biology tests. The transition between different infection types is multidirectional and conditioned by the following: susceptibility of epithelial cells to HPV-associated proliferation, impaired functioning of cell-mediated immune responses, tissue damage, action of steroid hormones and coexistence of infections caused by other viruses $[5,77]$.

\section{RRP epidemiology}

In the years 1970-1990 the incidence rate was at the level of 0.6-4.3 new cases annually per 100 thousand children; and it was lower in Europe when compared to other continents [78]. Based on the data from Centers for Disease Controland Prevention and Recurrent Respiratory Papillomatosis Task Force the incidence rate in Europe decreased to 0.24 in 2009 [78]. In the same period the average incidence rate in the USA was 0.73 and ranged from 0.12 to 2.13 depending on a state [79]. Discrepancies in the results are conditioned by many factors: geographical variations, different estimates of morbidity rates in different regions of the world, diffuse "distribution" of specific viral types in different populations. In Thailand the same rate is estimated at 2.8 and remains 12 times higher than in European countries, whereas in Africa it is 4 . In the USA nearly 1000 of new cases are diagnosed per 305 millions of people, and in the 62-million population of the United Kingdom 103 patients are under supervision of all ENT centres [79].

\section{Risk factors}

The confirmed presence of pointed or flat condylomas in the genital tract of a mother during a spontaneous labour increases the risk of RRP even 231 times when compared to cases without clinically apparent signs of infection [80]. However, the possibility of RRP in a child born under such conditions is less than 1\% [81]. A theory describing a vertical route of foetal infection during the passage through an infected birth canal $[82,83]$ is commonly accepted; the estimated risk of HPV infection transmission from a mother to a child during the passage is $1 / 80$ to $1 / 400$ births [84]. It has been demonstrated that children with RRP only exceptionally were born during a delivery by a caesarean section [5]. Nonetheless, the role of a caesarean section as a method to prevent HPV transmission appears to be limited.

A situation regarding an infection with highly oncogenic viruses is different. If an HPV 16 infection was diagnosed in the mother's cervix, the presence of the same viral type was observed in smears of the upper respiratory tract in as many as $50 \%$ newborns. Clinical studies also indicate an extrasexual route of infection transmission confirmed in 
newborns, infants and small children whose mothers were not infected with HPV. Moreover, the presence of papillomaviruses in the amniotic fluid and umbilical blood, and syncytiotrophoblast cells in pregnant women with an active infection in the cervix suggests a possibility of an intrauterine infection. A consequence of a perinatal infection can include RRP that develops after the period of several months or even years when the virus is lying dormant in macroscopically normal tissues [82, 84].

\section{Clinical manifestation of RRP}

In the course of RRP the number of cases has two peaks: between 2nd and 5th year of life, what is typical of a clinical form in children, and there are single cases in the period preceding puberty [85-87]. In the case when this disease develops in the first or second year of age [86], and in particular before the sixth month of life the prognosis is especially unfavourable, and in this last group the mortality rate reaches even $100 \%[88,89]$. Early disease development is correlated with HPV 11, associated with frequent relapses and the need to repeat endoscopic procedures to restore the patency of the respiratory tract at least four times a year. The risk of lesions spreading into the trachea, bronchi and pulmonary parenchyma is increased. When the disease develops later the clinical course is milder [77, 86, 89, 90]. In elderly patients HPV 6 is detected more often. In such cases the lesions are usually less numerous and cause critical disturbances associated with the respiratory tract obstruction relatively rarely [86].

\section{Identification of HR HPV DNA as a diagnostic tool in HNSCC cases}

The significance of the patient's assessment prior to treatment selection and introduction

The assessment of a patient with HNSCC of a primary location in the oropharynx includes molecular diagnostic tests for HPV as well as a classic histological examination. As a result it is possible: (1) to obtain a complete diagnosis, (2) to select HPV-associated cancers, (3) to inform the patient of a disease nature and a prognosis, (4) to schedule further treatment [21, 91-93]. With regard to current knowledge (ASCO 2012) HPV-associated cancers are subject to a different management model; due to a significantly better response to radiochemotherapy and a better prognosis their treatment has been deintensified, namely radiation doses have been reduced. As a result of this strategy it is possible to avoid complications or reduce side effects and achieve cure rates as high as previously [17, 94, 95]. An accurate diagnosis and classification into two different therapeutic pathways are of basic significance in order to compare treatment outcomes that have been achieved so far in different arms of phase II clinical trials and it is also a point to start designing phase III trials - it is a potential step towards individualised treatment [71, 97]. Treatment "deintensification" and efficacy of targeted treatment is still under debate $[97,98]$.

\section{An assessment of a tumour tissue from a specimen}

A histopathological assessment

In order to prepare biologically adequate classification based on morphological parameters and molecular markers the role of a pathologist and an increasing role of a laboratory diagnostician (who performs some assays that are combined with a medical diagnosis at a later stage) are more and more important. The regulation of diagnostic minima for a complete diagnosis of HPV-associated HNSCC is an urgent task that has not been accomplished yet. Due to a special role of HPV 16 it is recommended to introduce tests in order to confirm an infection, in particular in the case of OPCs. The determination of the HPV status for HPV-associated cancers can be performed using one test or a combination of several tests.

In accordance with the guidelines of College of American Pathologists (Tab. I and II) a histopathological examination has been supplemented with a requirement to add the $p 16^{I N K 4 A}$ assay, and the rules how to assess the HPV presence have been changed. Changes are quoted according to fragments of the protocol on how to prepare diagnostic material.

An assessment of a tumour tissue with molecular biology techniques

A general rule used to identify and genotype HPV is based on the detection of hybrids formed by specific DNA or RNA probes with complementary DNA fragments from a tested tissue sample. Differences in specificity and sensitivity of individual methods are associated with the method of material preparation (direct detection or the need to replicate viral DNA) and with methods to detect hybrids obtained. The test sensitivity is the lowest number of viral DNA copies in a cell that can be detected using a given technique.

The PCR (polymerase chain reaction) method is based on the replication of a studied DNA fragment. It makes it possible to detect one copy of a virus per ten cells. Moreover, it allows for simultaneous determination of many HPV types. The price associated with high sensitivity is susceptibility to contamination of a tested sample with a "foreign" DNA from outside the sample. GP5+/6+ starters are the most commonly used for the detection of HR HPV DNA in a PCR reaction. Moreover, commercially available HPV genotyping tests and sequencing methods are also used. This test can be performed using fresh or frozen tissue specimens as well as paraffin-embedded specimens and smears. Fresh or frozen tissue specimens are the best

Table I - Guidelines for completing the protocol histopathology

Additional examinations (required) [p16, HPV] (choose each of the following):

1. $p$ 16: positive or negative

2. Human papillomavirus (HPV):

a. in situ hybrydyzation (ISH). Type (to assess): positive: morphology: point, diffuse, heterogeneous; negative: indirect (to explain):

b. polymerase chain reaction (PCR). Type (to assess): positive/ negative 
Table II - Recommendations evaluation of HPV DNA in oropharynx squamous cell carcinoma based on the evaluation expression profile $p 16^{I N K 4 A}$ in immunohistochemical study

\begin{tabular}{|c|c|c|}
\hline Cancer morphology & $p 16^{\mathrm{INK} 4 \mathrm{~A}}$ & $\begin{array}{c}\text { Required examination to confirm } \\
\text { the presence of HPV DNA }\end{array}$ \\
\hline $\begin{array}{l}\text { Non-keratinising or non-keratinising } \\
\text { in the most part }\end{array}$ & $\begin{array}{l}\text { Strong and diffuse reaction } \\
\text { (cytoplasmic and nuclear, i.e. }>70 \% \text { ) }\end{array}$ & No \\
\hline $\begin{array}{l}\text { Non-keratinising or non-keratinising } \\
\text { in the most part }\end{array}$ & Negative or only focal positive reaction & Yes \\
\hline Keratinising & $\begin{array}{l}\text { Strong and diffuse reaction } \\
\text { (cytoplasmic and nuclear, i.e. }>70 \% \text { ) }\end{array}$ & Yes \\
\hline Keratinising & Negative or only focal positive reaction & No \\
\hline
\end{tabular}

material for tests. When selecting material for tests it is necessary to agree this with a laboratory.

Southern-blot or Dot blot methods have high sensitivity (from 0.1 to 1 DNA copy per cell) and specificity. They are based on the hybridisation of viral DNA with a complementary probe and make it possible to identify the whole viral genome. On the other hand, they require a large amount of material for the analysis, and are complex and time-consuming.

A separate group of tests based on a PCR technique includes the analysis of viral transcripts of the E6/E7 genes using RT-PCR (reverse transcriptase PCR). Reverse transcriptase PCR is one of the most sensitive methods of detecting low numbers of mRNA in a specimen. Thanks to RT-PCR it is possible to determine the level of viral expression. The test for viral oncogenes: E6 and E7 is thought to be a "gold standard" by some authors as these oncogenes interact with cellular proteins such as p53 and pRB. The viral E7 protein joins with $\mathrm{PRB}$ resulting in the release of the E2F factor from the pRB:E2F complex and the expression of proteins that are necessary for DNA replication, whereas the viral E6 protein interacts with the $\mathrm{p} 53$ protein. It has been demonstrated that the overexpression of viral E6 and E7 genes is necessary for the cells to start malignant transformation. Viral transcripts can be tested using fresh or frozen tissue specimens. Due to a very poor quality of RNA from paraffin-embedded specimens this material is not recommended for a routine use.

In situ hybridisation (ISH) is a method allowing for the analysis of viral transcripts directly in the studied tissue, and it does not require RNA isolation or amplification. The use of RNA probes for HPV E6/E7 makes it possible to analyse integration and transcriptional viral activity in the studied material. Thanks to the analysis of viral transcripts (mRNA HPV) using PCR methods or their direct visualisation in tissues using ISH it is possible to distinguish a chronic infection from a transitory one, and it can be a valuable supplement to diagnostic procedures.

Fluorescence in situ hybridisation (FISH) is another method to detect HPV DNA. This method is complex and requires a fluorescence microscope. An additional obstacle is an unassessable image being a result of e.g. a large number of signals of integration between HPV and the host genome. This test is characterised by high specificity but relatively low sensitivity - 85-88\%. Paraffin-embedded specimens can be used for this test.

An immunohistochemical assay for the $p 16^{\text {INK4A }}$ expression is a method of a direct analysis of malignant transformation associated with HPV in a cell. It is thought that the $p 16^{\text {INK4A }}$ overexpression is a result of binding of the pRB protein by the viral E7 protein and an interaction between the viral $\mathrm{E} 6$ protein and the $\mathrm{p} 53$ protein as a result of a negative feedback. Many authors claim that this test has very high sensitivity $90-100 \%$, but its specificity is low, $80 \%$, what may translate into a large share $(20 \%)$ of falsely positive results.

Summing up, in patients with OPCs it is absolutely necessary to assess HR HPV DNA. This test allows for viral identification, but it does not make it possible to assess its transcriptional activity. In HR HPV DNA (+) patients viral genotyping with special consideration for HPV 16 and 18 should be considered. The $p 16^{\text {INK4A }}$ expression test combined with the HPV DNA test increases the sensitivity of the assay. The HPV mRNA test may be a valuable supplement, but it is not absolutely required. It makes it possible to detect an integrated form of the virus. Among many methods to analyse HPV in a tumour tissue the following are used the most frequently: immunohistochemical (IH) detection of $p 16^{\mathrm{INK} 4 \mathrm{~A}}$, in situ hybridisation (ISH) and PCR. In the case of lymph nodes (diagnostic material collected with various techniques) immunohistochemistry is recommended in order to assess HPV 16 and/or $p 16^{\text {INK4A }}$.

\section{An attempt to establish a diagnostic algorithm}

The authors attempting to establish a diagnostic algorithm think that the diagnosis of HPV-associated HNSCC has to be based on two parameters combined: tumour features (HPV DNA or p16) and the HPV E6/7 test [99, 100]. A combined method of detecting HPV DNA using a PCR and GP5+/6+ starters, and an immunohistochemical analysis of the $p 16^{\mathrm{INK} 4 \mathrm{~A}}$ expression has sensitivity of $96-97 \%$ and specificity of $94-98 \%$. A potent relationship between the classification of a tumour as HPV-associated and a prognosis (assessed based on disease-dependent survival rates) is confirmed only when both parameters are used together. What is more, seronegative patients with regard to E6/E7 antibodies have a significantly higher risk of death despite the $p 16^{I N K 4 A}$ overexpression as this parameter can be modulated by other causative factors that are independent of HPV [101].

Cost-effectiveness is one of basic criteria for test selection. In the USA one assay is associated with the following costs: $p 16^{\text {INK4A }}$ IH $-\$ 25$, HPV DNA PCR with genotyping \$400, HPV DNA ISH - \$55, HPV RNA ISH - \$157, HPV RT-PCR for E6,E7 - \$150 [93].

In accordance with the guidelines of the National Comprehensive Cancer Network 2011 for head and neck cancers 
a single test which is recommended for OPCs in order to determine the prognosis is $p 16^{\mathrm{INK} 4 \mathrm{~A}} \mathrm{IHC}$; its value has been proven, it is widely available, inexpensive, easy to interpret and with clear recommendations regarding the cut-off value [93]. In order to confirm the value of this method two clinical studies RTOG-1016 and RTOG-0920 have been started.

An assessment of a brush smear

This test should be considered if tissue material is not available. The assessment of an HPV infection should be performed with the HR HPV DNA test. Due to a very low amount of cellular material that can be obtained from a smear and lack of commercially available tests that have been validated using material from ENT smears this test might not be available.

A suggested management regimen in patients with oropharyngeal cancers

(Fig. 1)

Quality standards in diagnostic procedures for HPV, an assessment of their quality and a diagnostic value and laboratory interpretation and authorisation of laboratory results

Collecting and transporting material for HPV DNA tests A laboratory performing a HPV DNA test provides a test order form, detailed instructions on how to collect, store and transport samples.

\section{Smear collection}

A smear should be collected with a brush or a nylon swab from suspected places, and then suspended in a transport medium that has been validated by a laboratory. It is recommended to secure material in a buffer for liquid-based cytology and an HPV test. The amount of the transport medium should not exceed 1.5-5 ml. Cells collected with this method are well preserved, and as a result they can be transported at room temperature $\left(15-30^{\circ} \mathrm{C}\right)$ and it will not have an adverse effect on the test results. Closed test tubes with cells suspended in a liquid transport medium should be stored in accordance with the manufacturer's guidelines. The collection and transport system has to always be validated against a used diagnostic test in order to avoid preanalytical errors and to provide reliable results. Test tubes with smears have to include the following patient's data: full name, PESEL (personal id. no.) and a collection date or a barcode.

Tissue material

Tissue fragments for the HPV DNA test with a PCR method can be frozen or suspended in a test tube with a medium for liquid-based cytology and the HPV test, and then stored in a fridge (temp. $2-8^{\circ} \mathrm{C}$ ).

Transport of material for laboratory tests

Smears or fresh tissue fragments secured in a medium for liquid-based cytology and the HPV test can be transported at room temperature. Transport at temperature $2-8{ }^{\circ} \mathrm{C}$

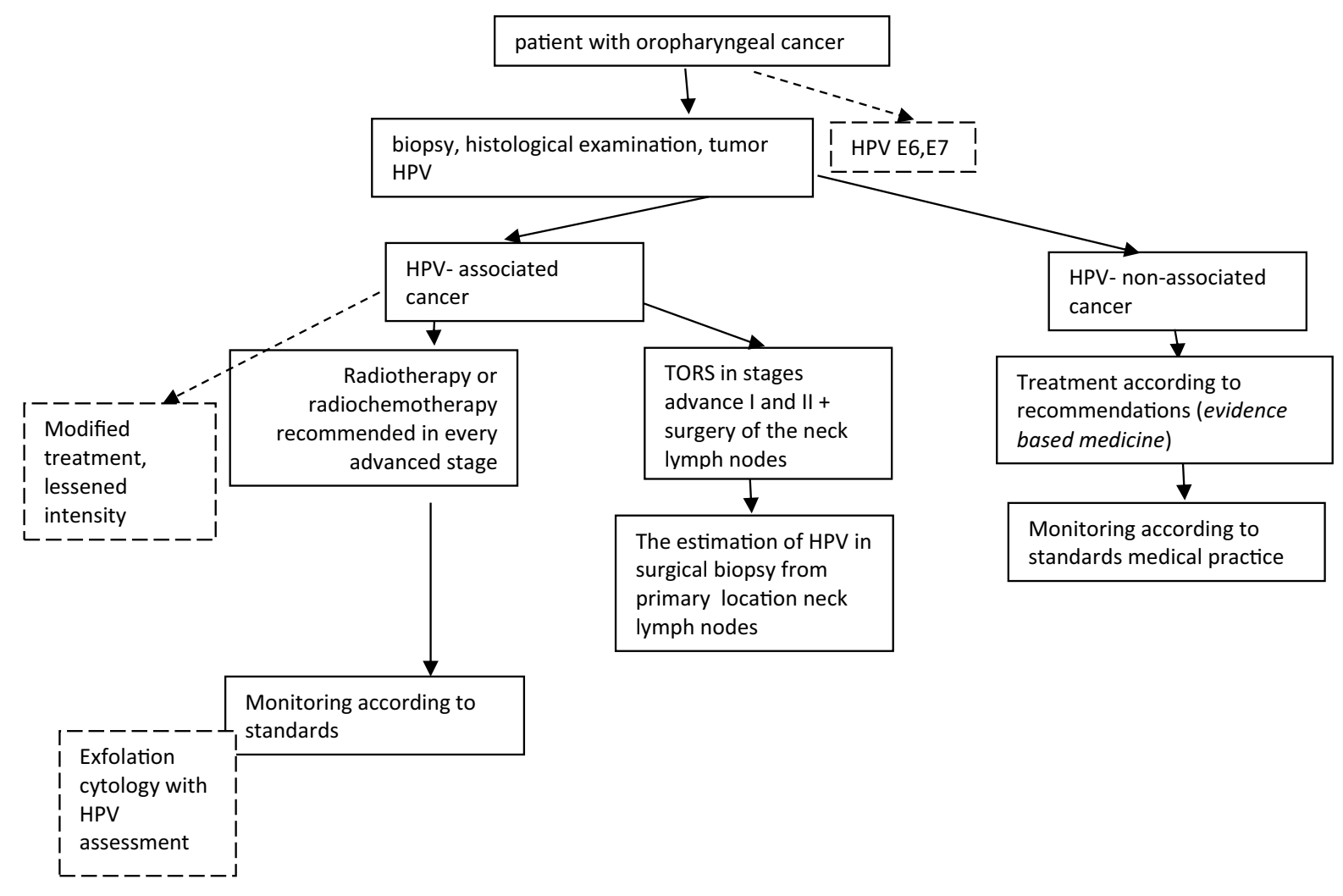

Fig. 1 - Diagram of oropharyngeal cancer patient treatment 
provides additional protection. With regard to transport of frozen material its thawing and refreezing have to be avoided. Material is transported in closed test tubes or in containers, in a closed collective package labelled "infectious material".

\section{Test methods}

A laboratory uses test methods that correspond to current medical knowledge and have been appropriately validated by this laboratory.

\section{Falsely negative results}

Falsely negative results can be obtained when there is a too low number of cells collected for a test, or a sample was stored inappropriately or sample transport conditions were inappropriate, or there were analytical errors. In HPV DNA molecular diagnostics it is necessary to use tests with an internal cellular control (i.e. amplification and detection of the $\beta$-globine gene) that provides information whether the following steps were performed correctly: smear collection, DNA extraction and amplification processes, and moreover, it protects against issuing a falsely negative result.

Falsely positive results

High sensitivity of molecular methods to detect HPV DNA is associated with a risk of falsely positive results due to contamination of a tested sample by low amounts of DNA from other patients. Therefore it is recommended to use tests with enzymatic protection against issuing a falsely positive result due to contamination (i.e. UNG and dUTP).

\section{Presentation and issuing results of HPV DNA tests}

The report form presenting results of the HPV DNA test is in accordance with the ordinance of the Minister of Health and has been authorised by a laboratory diagnostician with a title of a specialist in laboratory medical genetics or medical microbiology, with at least 2-year experience in molecular diagnostics. The report form regarding laboratory tests can be transferred in an electronical form what complies with legal requirements.

\section{Requirements regarding a laboratory}

A laboratory has to meet quality standards stated in the ordinance of the Minister Health on quality standards for medical diagnostic and microbiological laboratories, in particular:

- it prepares, implements and uses procedures to accept, register and attach laboratory labels on study material and makes the procedures available to ordering parties that confirm they have familiarised themselves with these procedures,

- it performs an internal quality control of tests and participates in an external quality control in accordance with the ordinance of the Minister of Health.

(ORDINANCE OF THE MINISTER HEALTH of 12 January 2011 on basic principles and procedures of conformity assessment for in vitro diagnostic medical devices;
ORDINANCE OF THE MINISTER OF HEALTH of 3 March 2004 on the requirements for a medical diagnostic laboratory;

ORDINANCE OF THE MINISTER HEALTH of 21 January 2009 changing the ordinance on the quality standards for medical diagnostic and microbiological laboratories [102-104])

NOTE!

Laboratory tests performed according to recommendations and principles stated above should always be correlated with a routinely performed histopathological test that is assessed by a medical professional specialising in pathomorphology. When diagnostic procedures are limited only to HPV diagnostics it is not possible to distinguish whether a lesion is mild (and is only proliferative) or whether it is in situ carcinoma or invasive cancer.

\section{LR HPV DNA identification in RRP}

Studies that have so far been conducted in populations of children are not systematised, and are only of an exploratory nature; moreover, they are conducted based on heterogeneous protocols and using different techniques [105]. Factors affecting large discrepancies in results obtained are associated with the sensitivity of test methods used to identify LR HPV DNA [77].

In the table below there are specific features of selected molecular biology techniques commonly used to identify genetic material of the human papillomavirus in tissue specimens (Tab. III).

\section{Summary}

\section{State of knowledge and directions of studies in the field of $H R$} HPV

1. Meta-analyses presented in the literature unambiguously prove the role of HPV in the development of HNSCC, in particular oropharyngeal cancers.

2. Incidence trends unambiguously indicate an increasing number of HPV-associated head and neck cancers, first of all located in the oropharynx.

3. The presence of HPV as a biological feature of a cancer is a documented favourable prognostic factor for pharyngeal cancers; however, the role of HPV remains unclear with regard to other primary locations of HNSCC.

4. The method to detect HPV in patients with HNSCC has been prepared and standardised. A routine test for cancers of the oral cavity and oropharynx with regard to the HPV status is recommended as a standard procedure.

5. So far risk groups have not been selected and no screening tests have been undertaken to allow for early diagnostics of precancerous conditions of the oral cavity and oropharynx in combination with an HPV infection.

EUROGIN 2011 [2] - a road map presenting prophylaxis and treatment of HPV-associated diseases points at the following future directions of studies: 
Table III - Comparison of the molecular biology techniques used in the detection DNA sequences of human Papilloma virus

\begin{tabular}{lllll} 
Methods & Sample types & $\begin{array}{c}\text { Methods sensitivity } \\
\text { (minimum amount of } \\
\text { HPV DNA detected in } \\
\text { one cells) }\end{array}$ & Methods profile \\
\cline { 3 - 5 } $\begin{array}{l}\text { FISH fluorescence in situ } \\
\text { hybridization with filters }\end{array}$ & Homogenate tissue & $10-100$ & Fast examination & $\begin{array}{l}\text { Low sensitivity, quite } \\
\text { low specificity }\end{array}$ \\
\hline $\begin{array}{l}\text { NISH non-isotopic in situ } \\
\text { hybridization }\end{array}$ & $\begin{array}{l}\text { Tissue histological } \\
\text { and cytological slides }\end{array}$ & 20 & $\begin{array}{l}\text { Direct HPV } \\
\text { examination } \\
\text { in tissue cells }\end{array}$ & $\begin{array}{l}\text { Low sensitivity, substantial } \\
\text { labour-consumption }\end{array}$ \\
\hline Southern Blot & Purificated DNA & $\begin{array}{l}0,1-1(\text { amount of examined } \\
\text { DNA 5-10 } \mu g)\end{array}$ & High specificity & $\begin{array}{l}\text { Abundance of sample substantial } \\
\text { labour-consumption }\end{array}$ \\
\hline Dot Blot & Purificated DNA & $1-10$ & High specificity & Substantial labour-consumption \\
\hline PCR & $\begin{array}{l}\text { Purificated DNA, } \\
\text { tissues, smears, }\end{array}$ & 1 copy in whole sample & $\begin{array}{l}\text { High sensitivity, } \\
\text { genotyping } \\
\text { possibility, fast } \\
\text { examination }\end{array}$ & High contamination risk \\
\hline
\end{tabular}

1. The assessment of an HPV infection in HNSCC (located outside the oropharynx).

2. A molecular assessment of improved results of treatment with radiochemotherapy in the case of HPV-associated HNSCC.

3. An assessment of the incidence rate in the population for an HPV infection of the oral cavity and HPV distribution in different parts of this anatomical location.

4. A test of a natural history of an HPV infection of the oral cavity.

5. The efficacy of HPV vaccines in the prophylaxis of HPV 16 infections of the oral cavity.

6. A potential use of HPV tests in a screening programme for infections of the oral cavity.

7. A precise characteristics of HPV-positive precancerous conditions.

Items not covered by the EUROGIN 2011 programme:

1. Using the level of antibodies against HPV to monitor patients treated for HPV-associated HNSCC; initial reports indicate that the levels of E6 and E7 expression which are reduced in the period after treatment in comparison with the baseline might be associated with remission and elevated levels suggest a persistent cancer or a relapse $[48,106,107]$.

2. The assessment of LR HPV in papillomatous laryngeal cancers; a LR HPV coinfection may be a reason to change selected treatment (radiation therapy replaced by surgery).

State of knowledge and directions of studies in the field of LR HPV

So far there are no recommendations for routine identification of HPV genotypes in the course of RRP in children. BAPO/ ASPO (British Association of Paediatric Otorhinolaryngology/ American Society of Paediatric Otolaryngology) recommendations regarding the assessment of shares of individual HPV types in cases with an aggressive RRP course:

1. The presence of symptoms during the first two years of life.

2. Frequent relapses requiring restoring patency of the respiratory tract at least four times a year.
3. Spread of papillomatous lesions below the level of the glottis.

Identification of HPV in the mucous membranes of the upper respiratory tract in children without RRP:

1. Born as a result of a spontaneous labour by mothers with a clinically apparent HPV infection in the genital tract.

2. Born by mothers with a documented infection with highly oncogenic HPV types.

3. Victims of sexual abuse.

Summing up, despite lack of a finally established algorithm and fully validated test methods it is necessary to determine the presence of HPV in cases where the value of such diagnostic procedures have been proven, namely in the oropharyngeal cancers and in selected cases of recurrent respiratory papillomatosis.

\section{Wprowadzenie}

Rola wirusów brodawczaka ludzkiego (HPV) w patogenezie chorób jamy ustnej, gardła, krtani i masywu szczękowo-sitowego

Dotychczas poznano 200 różnych typów wirusa HPV (Human papillomavirus). Grupę tę można podzielić na: $\alpha, \beta, \gamma, \mathrm{Mu}$ i Nu. Część spośród wspomnianych genotypów wirusa jest przenoszonych drogą płciową. Z uwagi na ich zróżnicowany potencjał onkogenny wyróżnia się wirusy HPV wysokiego ryzyka (HR; high risk) tj. HPV 16, HPV 18, HPV 31, HPV 33 i HPV 45 , związane $z$ przeszło $80 \%$ raków szyjki macicy oraz o niskim potencjale onkogennym (LR; low risk), tj. HPV 6 i HPV 11 związane z łagodnymi zmianami śródnabłonkowymi niższego stopnia (low-grade) lub z rozwojem brodawczaków krtani. Wirusy należące do grupy $\beta$ infekują skórę, natomiast pozostałe wirusy (grupy $\gamma, \mathrm{Mu}$ i $\mathrm{Nu}$ ) są odpowiedzialne za powstanie brodawek, które z reguły nie ulegają transformacji nowotworowej [1].

Zakażenia wirusem HPV HR są odpowiedzialne za 600000 przypadków raków szyjki macicy, sromu, pochwy, odbytu, jamy ustnej i ustnej części gardła, rozpoznawanych rocznie na świecie. Ponadto są czynnikiem sprawczym 
kłykcin i nawracających brodawczaków układu oddechowego. Podczas gdy występowanie raków szyjki macicy obniża się od wielu dekad, raki odbytu oraz raki głowy i szyi stanowią narastający problem. W następstwie takiej sytuacji powstał multidyscyplinarny projekt badawczy Eurogin 2011 [2] dotyczący prewencji i leczenia chorób HPV-zależnych i podejmujący zagadnienia chorobowości, ewidencji, rekomendacje diagnostyczno terapeutyczne.

\section{Raki głowy i szyi}

Raki płaskonabłonkowe (HNSCC; head neck squamous cell carcinoma) wywodzą się z nabłonka płaskiego wyściełającego górne drogi oddechowe i górny odcinek drogi pokarmowej. Jest to heterogenna grupa nowotworów, rozwijającą się w różnych lokalizacjach pierwotnych, o wspólnych czynnikach ryzyka i podobnych cechach patologicznych. Ich etiologia jest wieloczynnikowa, a rozwój obejmuje wielostopniową kancerogenezę poprzedzoną zmianami dysplastycznymi błony śluzowej. Zgodnie z klasyfikacją ICD-10 [3], dla HNSCC wyróżniamy następujące lokalizacje pierwotne: język (C01,9-C02,9); dziąsło (C03,0-C03,9); dno jamy ustnej (C04,0-C04,9); podniebienie (C05,0-C05,9); inne lokalizacje jamy ustnej (C06,0-C06,9); migdałek (C09,0-C09,9); część ustna gardła (C10,0-C10,9); część krtaniowa gardła (C12,9; C13,0-C13,9); inne lokalizacje gardła (C14,0; C14,2-C14,8); krtań (C32,0-C32,9).

\section{Rola wirusów HPV w rozwoju HNSCC}

W ostatnich dekadach badania epidemiologiczne i molekularne wskazały na rolę wirusów brodawczaka ludzkiego w rozwoju pewnych grup HNSCC. Udział HPV w kancerogenezie raków jamy ustnej i ustnej części gardła został po raz pierwszy zasugerowany przez zur Hausena w 1999 [4] i Syrjanen w 2005 roku [5], a potwierdzony przez grupy badawcze Erdmanna [6], Naira [7] i Gillison [8] w oparciu o następujące spostrzeżenia: tropizm wirusa HPV do komórek nabłonkowych, zmiana genomu ludzkich keratynocytów $\mathrm{w}$ badaniach in vitro, szeroko udokumentowany onkogenny potencjał podtypów HPV HR w rozwoju raka szyjki macicy oraz morfologiczne podobieństwo nabłonka jamy ustnej i gardła oraz nabłonka układu moczowo płciowego. Obecność DNA HPV w stanach przedrakowych i rakach inwazyjnych jamy ustnej jest trzy- i pięciokrotnie wyższa w porównaniu z prawidłową błoną śluzową [5, 9]. Występowanie infekcji HPV HR w rakach jamy ustnej sięga 25\%, a wirus HPV 16 jest stwierdzany w 70\% tkanek raków HPV-pozytywnych; w rakach ustnej części gardła odsetki te są wyższe i wynoszą odpowiednio 35\% i 90\% [8, 10, 11]. Typ $16 \mathrm{HPV}$ jest związany z czterokrotnym wzrostem ryzyka rozwoju HNSCC.

Poszczególne lokalizacje pierwotne różnią się znacząco co do predylekcji rozwoju i częstości występowania HPV HR w HNSCC: istotnie częściej występuje w ustnej części gardła w porównaniu z jamą ustną i krtanią [5, 12-17]. Obecność wirusa HPV HR w tkance nowotworu stała się podstawą do wyróżnienia odrębnej grupy HNSCC: raków HPV-zależnych.

Raki HPV-zależne mają odmienną charakterystykę biologiczną związaną z profilem ekspresji genów, częstością mutacji TP53 i ekspresją p16. W badaniu histologicznym wykazują słabe zróżnicowanie [18]. Średnia wieku pacjentów z rakami HPV-zależnymi jest istotnie niższa, udział nałogów uznawanych za klasyczne czynniki ryzyka: palenie papierosów i picie alkoholu jest znacząco mniejszy lub ujemny, odmienne są zwyczaje seksualne: większa liczba partnerów $\mathrm{i}$ seks oralny. Powiązanie guza $\mathrm{z}$ wirusem HPV 16 to udokumentowany czynnik rokowniczy: lokoregionalnie zaawansowane raki gardła charakteryzują się w 60\% niższym ryzykiem śmierci i w 30\% lepszym 5-letnim czasem przeżycia [19-21]. Różnica w 5-letnich odsetkach przeżyć całkowitych jest wypadkową wielu czynników: młodszego wieku, lepszego stanu ogólnego, mniejszej liczby obciążeń, wyższego odsetka odpowiedzi na radio-chemioterapię i niższego ryzyka rozwoju drugich nowotworów pierwotnych. Palenie ponad 10 papierosów dziennie redukuje korzystniejsze szanse przeżycia dla pacjentów z HPV-zależnym HNSCC [17, 22-25]. Pomimo bardziej agresywnego przerzutowania do układu chłonnego szyi rokowanie nadal pozostaje lepsze niż w rakach HPV-niezależnych [26].

Przedmiotem kontrowersji pozostaje rola HPV LR. Typy HPV 6 i 11 stwierdza się w niewielkim odsetku HNSCC, lecz nie są one uważane za „całkiem łagodne" w regionie głowy i szyi [27]. Udowodniono, że łagodne brodawczaki o etiologii HPV 6 i 11 ulegają przemianie złośliwej pod wpływem napromieniania. Potwierdza tę obserwację agresywny przebieg obserwowany w rakach brodawkowatych dróg moczowych. HPV LR stwierdza się u 25\% HNSCC i ta grupa wykazuje gorsze wyniki leczenia radiochemioterapią. Koinfekcja HPV LR wymaga dalszych badań, które mogą w przyszłości stanowić przyczynek do zmiany strategii leczenia (radioterapii na rzecz chirurgii).

\section{Częstość występowania HPV-zależnych HNSCC}

W Europie częstość występowania HPV-zależnych HNSCC waha się od $20 \% \mathrm{w}$ Holandii do $41 \%$ w Szwajcarii, 55\% w Niemczech i $62 \%$ we Francji. W USA odsetki są wyższe, od $64 \%$ do $72 \%$. Rozbieżność wyników wynika z: 1) różnic etniczno-geograficznych, 2) różnej czułości stosowanych metod diagnostycznych (zróżnicowane materiały: biopsja, zeskrobiny, wymazy, wymazy szczoteczkowe, wycinki), 3) odmiennego przechowywania i obróbki materiału (świeży, mrożony, skrawki parafinowe po obróbce w formalinie), 4) metody wykrywania HPV $[28,29]$.

Od lat 80. zapadalność na HNSCC stopniowo obniża się, zwłaszcza w USA, w związku z ograniczeniem klasycznych czynników ryzyka: palenia tytoniu i spożycia alkoholu. Równolegle $z$ tym trendem obserwuje się zróżnicowanie liczby zachorowań w zależności od powiązania HNSCC z wirusem HPV. Ostry wzrost zachorowań na HPV-zależne HNSCC notuje się na całym świecie, w Europie ten pik jest wyższy niż w USA [30]. Istotny wzrost zachorowań zanotowano dla lokalizacji pierwotnych o wysokim odsetku raków HPV-zależnych: raków migdałka i nasady języka z równoległym wzrostem infekcji HPV w obrębie jamy ustnej i gardła [13, 31-35]. Równocześnie w lokalizacjach HPV zależnych rośnie zapadalność na raki w niższych grupach wiekowych (45-54) w porównaniu z kohortami starszymi. Wzrost zachorowań jest najwyższy wśród mężczyzn w grupie wiekowej 40-64 lat. Częściowo tłumaczy to częstość zakażenia HPV HR narządów płciowych: 
w zdrowej populacji od 29-65\% wśród mężczyzn i 25\% wśród kobiet. Zakażenie jamy ustnej odpowiednio wynosi $10 \%$ i 3,6\%. Ponadto występują różnice immunologiczne u obu płci i wyższa liczba partnerów seksualnych u mężczyzn [36-38].

\section{Czynniki ryzyka rozwoju HPV-zależnych HNSCC}

Przyczyny wzrostu liczby przypadków raków HPV-zależnych nie są jasne, wydają się być związane ze zmianami nawyków seksualnych. Zakażenie jamy ustnej wirusem HPV jest powiązane z cztero- do dwunastokrotnie wyższym ryzykiem rozwoju HNSCC. Udowodniono: 1) bezpośrednią zależność pomiędzy zakażeniem wirusowym narządów płciowych a obecnością infekcji HPV jamy ustnej, 2) obniżonym wiekiem inicjacji seksualnej, 3) dużą liczbą partnerów, 4) brakiem stosowania prezerwatyw, 5) seksem oralnym. Źródłem transmisji wirusa i czynnikiem sprzyjającym są także pocałunki z otwartymi ustami. Wyższe odsetki raków migdałka stwierdzono u partnerów kobiet chorujących z powodu raka szyjki macicy. Synchroniczne raki jamy ustnej potwierdzono u partnerów zakażonych tym samym podtypem wirusa HPV [25, 39-41]. Nie prowadzono długofalowych badań nad transmisją HPV wśród partnerów seksualnych. Potwierdzono wyższe ryzyko zakażeń wirusem HPV u osób z immunosupresją posttransplantacyjną i zakażonych HIV.

\section{Zakażenia HPV specyficzne dla poszczególnych lokalizacji pierwotnych HNSCC}

\section{Stany przedrakowe jamy ustnej}

Występowanie DNA wirusa HPV w zmianach przedrakowych jamy ustnej i gardła oceniane jest w szerokich granicach od 0-85\%, z przewagą genotypów HPV 16 i 18 [42]. Miller i wsp. oraz White i wsp. [43, 44] identyfikowali HPV w $43 \%$ preparatów świeżych lub mrożonych i $12 \%$ parafinowych pochodzących ze zmian klinicznie ocenionych jako leukoplakia natomiast niezawierających dysplazji $\mathrm{w}$ badaniu patologicznym. Zdecydowanie silniejsze powiązanie $\mathrm{z}$ występowaniem HPV ma leukoplakia brodawkowata, która jest rzadką i agresywną formą proliferującej leukoplakii o wysokim (90\%) ryzyku przemiany złośliwej, oporna na leczenie, występująca głównie u kobiet w podeszłym wieku. Jej etiologia nie łączy się z paleniem papierosów czy infekcją grzybiczą, a HPV 16 potwierdzono w odsetku sięgającym 25,5-80\%. Z kolei w lichen planus nie potwierdzono jednoznacznie udziału zakażenia wirusem, $\mathrm{z}$ wyjątkiem przypadków klinicznie przebiegających $\mathrm{z}$ owrzodzeniem, które powiązano $z$ genotypem HPV 18 [42, 45].

Raki części ustnej gardła (OPC-oro-pharyngeal-cancer) Liczba zachorowań na OPC na świecie to 137000 przypadków, a liczba zgonów sięga 96000 rocznie; 61500 raków wywodzi się z okolic anatomicznych, w których kancerogeneza ma udokumentowany związek przyczynowy z HPV (migdałek podniebienny, nasada języka).

Dystrybucja HPV u chorych z OPC była szacowana w szerokich granicach, od 5-70\% [9]. Ostatnia metaanaliza [30] wykazała do roku 2000 udział zakażeń HPV rzędu 41\%, do 2004 - 72\% i wzrost po roku 2004 do 96\%. Występowanie
HPV w OPC jest wyższe w USA (60\%) niż w Europie (40\%, projekt EUROCARE) i innych częściach świata (33\%). Wzrostowe trendy zachorowań na OPC oraz rosnąca częstość infekcji HPV zostały potwierdzone przez wszystkich badaczy, niezależnie od badanej populacji i zastosowanej metodologii. W USA liczba raków HPV zależnych wzrosła o 225\%, a niezwiązanych z HPV spadła o 50\% [17].

W ciągu ostatnich dwóch dekad HPV jako główny czynnik sprawczy kancerogenezy zastąpił palenie papierosów i spożycie alkoholu. Podkreśla się wirulencję HPV i dalekosiężne konsekwencje tej infekcji: całkowite ryzyko rozwoju OPC u alkoholików wynosi 5,5, u nałogowych palaczy papierosów 19,5, przy synergistycznym działaniu obu nałogów 56,5, a przy zakażeniu HPV 230,0 [47]. Większość HPV-zależnych OPC jest powiązana wyłącznie z HPV 16 (84$87 \%$ raków migdałka podniebiennego). Pozostałe typy: 18, 33, 35 są odpowiedzialne za niewielki odsetek zachorowań. Około 3\% raków może być wywołanych zakażeniem HPV LR: 6 i 11.

Wpływ zakażenia wirusem HPV na rokowanie w OPC jest udokumentowany. Redukcja ryzyka niepowodzenia dla raków HPV-zależnych wyniosła 15\%, a ryzyko zgonu było niższe o 38\% [48]. Protokół ECOG (European Cooperation Oncology Group) II fazy i TROG 02.02 oraz TAX III fazy jednoznacznie wskazały, że HPV w tej lokalizacji wiąże się $\mathrm{z}$ istotnie lepszym rokowaniem [49]. Dla HPV-zależnych OPC w stopniu zaawansowania narządowego III/IV ECOG zakończyła rekrutację pacjentów do badań II fazy opartych na deintensyfikacji leczenia radiochemioterapią. Doniesienia na temat wyników chirurgii TORS dla raków HPV-zależnych i niezależnych nie są jeszcze ostatecznie znane.

\section{Raki jamy ustnej}

Rola wirusa HPV w kancerogenezie raków jamy ustnej pozostaje kontrowersyjna. Metaanaliza Syrjanen [50] wykazała czterokrotny wzrost ryzyka zachorowania na raka jamy ustnej u chorych z infekcją HPV 16, niemniej tak oszacowany poziom ryzyka okazał się identyczny jak dla przemiany złośliwej stanów przedrakowych. Analiza Ribeiro [51] nie potwierdziła statystycznie istotnego związku pomiędzy zakażeniem HPV a rakami jamy ustnej. Najczęstszym typem HPV wykrywanym w rakach jamy ustnej jest HPV 16 - jedynie doniesienia z Południowej Afryki [52] wskazywały wyłącznie na HPV 18, natomiast koincydencja obu podtypów jest częsta [53]. Rzadziej wykrywane typy to HPV 8, HPV 31, HPV 38, HPV 66 [54]. Równie rzadko wykrywane HPV LR stanowią czynnik biernie towarzyszący (bystander), a nie torujący (driver) kancerogenezę.

DNA HPV stwierdza się w 25\% raków jamy ustnej. HR HPV E6/E7 RNA jest obecne w 85\% raków HPV-zależnych i w 33,7\% ogółu raków w tej lokalizacji. Konfrontacja wirusa HPV z klasycznymi czynnikami ryzyka wskazuje na przewagę palenia papierosów (ryzyko raka u palaczy i nadużywających alkoholu pozostaje istotnie wyższe niż u pacjentów seropozytywnych) [16]. Nie ma także dowodów na lepsze rokowanie w rakach HPV-zależnych [55] - jest to jedynie trend, który nie osiąga istotności statystycznej [53]. Powyższa lokalizacja pierwotna wymaga dalszych badań precyzujących rolę HPV jako potencjalnego czynnika sprawczego i rokowniczego. 


\section{Raki krtani}

DNA HPV jest wykrywane w około 9,6\% prawidłowych krtani. Niewiele wyższy jest (do 23\%) odsetek HPV stwierdzany w rakach tego narządu. Najczęściej wykrywanym typem wirusa w rakach krtani jest HPV 16, niemniej dla HNSCC w tej lokalizacji stwierdzono największe zróżnicowanie typów: HPV 18, 26, 31, 33, 39, 36, 45, 51, 52, 58, 59, 66 i 69 [56-58]. Nie stwierdzono różnic demograficznych. Aktywność transkrypcyjną HPV odnotowano w nielicznych przypadkach, choć liczba kopii wirusa w guzach była istotnie wyższa niż w zmianach niezłośliwych. To podtrzymuje teorię o ,torującej” roli HPV w tej lokalizacji anatomicznej [59]. Nie stwierdzono wpływu HPV na rokowanie w rakach krtani [60]. Uważa się, że wirus może być jednym z promotorów kancerogenezy, nie jest jednak samodzielnym izolowanym czynnikiem sprawczym.

\section{Guzy masywu szczękowo-sitowego}

Dane dotyczące bezobjawowych „nosicieli” HPV w jamie nosa są nieliczne, a w polipach występują w niespełna $3 \%$ [61]. Związek etiologiczny pomiędzy HPV a brodawczakami odwróconymi (IP; inverted papillomas) jest udokumentowany - DNA wirusa jest wykrywane w około $25 \%$ guzów. Odsetek HPV istotnie rośnie w IP zawierających dysplazję wysokiego stopnia i w IP z ogniskami raka. W etiologii łagodnych IP potwierdzono rolę HPV LR i wysunięto tezę, że HPV HR są odpowiedzialne za przemianę $\mathrm{w}$ raki złośliwe i ich szybką progresję [62].

Doniesienia dotyczące roli HPV w rakach masywu szczękowo-sitowego są skąpe, opierają się na niewielkich, niejednorodnych grupach badawczych i uwzględniają zróżnicowane utkania guzów. DNA HPV stwierdza się w około 21-30\% raków, a najczęściej wykrywanym typem jest HPV 16. Nie można wyciągnąć ostatecznych wniosków co do wpływu HPV na przebieg kliniczny i rokowanie ze względu na dotychczasowe niedostateczne doświadczenia [63].

\section{Guzy gruczołów ślinowych}

Doniesienia literaturowe co do roli wirusa HPV w rozwoju nowotworów gruczołów ślinowych są nieliczne, oparte na małych liczebnie grupach (do 20 pacjentów), a wyniki badań rozbieżne. Wykryto, że HPV HR są czynnikiem promującym kancerogenezę w rakach śluzowo-naskórkowych, których częstość występowania rośnie w ostatnich dwóch dekadach [64]. Obecność DNA HPV stwierdzano także w guzach Whartina, gruczolakach wielopostaciowych, rakach zrazikowych [65], a najwyższy odsetek w rakach torbielowato-gruczołowych [66]. Znaczenie HPV w rozwoju guzów ślinianek nie jest ostatecznie udokumentowane, niemniej ostatnie doniesienia są sceptyczne [67].

Program badań przesiewowych i prewencja raków HPV-zależnych

Prowadzone programy przesiewowe mają na celu wczesne wykrycie zmian, a w konsekwencji ograniczenie zachorowalność i umieralność na nowotwory. W krajach, gdzie prowadzone są przesiewy cytologiczne, udało się w znaczny sposób ograniczyć zachorowalność i umieralność kobiet z powodu raka szyjki macicy. Czynnikiem niezbędnym do inicjacji i progresji zmian dysplastycznych w obrębie szyjki macicy jest infekcja onkogennymi typami ludzkiego wirusa brodawczaka. Wykazano, że przesiewowe badania cytologiczne w połączeniu z diagnostyką HPV są bardziej czułe w wykrywaniu neoplazji szyjki macicy (CIN; cervical intraepithelial neoplasia) niż prowadzone oddzielnie. Odpowiednio wczesne wykrycie stanu przedrakowego umożliwia podjęcie efektywnej, taniej i szybkiej terapii pozwalającej uzyskać prawie $100 \%$ powodzenie leczenia.

Odpowiedzią na nagły i niewyjaśniony wzrost zachorowań na HPV-zależne HNSCC była próba zaprojektowania w 2011 pierwszego badania przesiewowego, analogicznego do cytologicznego badania szyjki macicy. Udowodniono [68], że w cytologii złuszczeniowej jamy ustnej obecność infekcji HPV była istotnie niższa w grupie kontrolnej niż $\mathrm{u}$ chorych z rakiem. Ponadto istnieją dowody kliniczne, że DNA HPV uzyskane w wymazie szczoteczkowym wskazuje na wyższe ryzyko rozwoju raka lub wystąpienia wznowy miejscowej po zakończonym leczeniu [69]. W badaniu przesiewowym [70] porównywano dwie grupy chorych: zgłaszających się z powodu dolegliwości w zakresie gardła i osoby zakażone wirusem HIV, u których ryzyko rozwoju raka migdałka jest dwa- do sześciokrotnie wyższego od populacyjnego. Nie stwierdzono powiązania infekcji HPV 16 z atypowym obrazem komórek płaskonabłonkowych lub cechami dysplazji i badanie przesiewowe oceniono negatywnie.

Aktualnie nie ma prostego i wiarygodnego narzędzia do podjęcia badań przesiewowych infekcji HPV jamy ustnej i ustnej części gardła. Nie opracowano powszechnie akceptowanego testu przesiewowego dla stanów przedrakowych jamy ustnej [39]. Wprowadzenie w Wielkiej Brytanii rutynowego badania HPV metodą PCR jako części programu przesiewowego doprowadziło do obniżenia ceny testów. Stanowią one obecnie ułamek kosztów całego programu onkologicznego, niemniej nie ma dowodów potwierdzających zależność kosztu i efektywności tego postępowania [71].

Szczepienie czterowalentną szczepionką przeciwko HPV ma ugruntowaną wartość w prewencji raka szyjki macicy $\mathrm{u}$ kobiet. Nie ma natomiast danych o zapobieganiu transmisji i ekspresji onkogennych HPV jamy ustnej, choć istnieją przesłanki o potencjalnej efektywności szczepień w tym zakresie [72]. W USA rozważano szczepienia przeciwko HPV 16, 18 u chłopców. Ze wstępnej analizy wynika, że nie ma to uzasadnienia przy pełnym pokryciu szczepieniem populacji kobiet i nie wykazuje należytej efektywności kosztów [73]. Problematyka szczepień jako prewencji OPC pozostaje otwarta i wymaga wieloośrodkowych badań.

\section{Nawracająca brodawczakowatość układu oddechowego (RRP; Recurrent Respiratory Papillomatosis)}

RRP u dzieci jest najczęstszą niezłośliwą chorobą nowotworową dróg oddechowych w tej grupie wiekowej. Uważa się, że każda interakcja ludzkiego wirusa Papilloma z komórką podatną może wywołać zakażenie [74, 75]. Przyjmując 
jako kryterium podziału możliwości diagnostyczne, wyróżnia się trzy podstawowe rodzaje infekcji [75, 76]: kliniczna (jawna) - występowanie makroskopowo widocznych, płaskich bądź egzofitycznych, a czasami nawet balotujących tworów brodawczakowatych, subkliniczna - wykazywana jedynie w trakcie badania histologicznego, latentna (utajona) nie wywołuje uchwytnych zmian makroskopowych i mikroskopowych, a postawienie właściwego rozpoznania możliwe jest w oparciu o wyniki badań technikami biologii molekularnej. Przejście pomiędzy poszczególnym rodzajami infekcji ma charakter wielokierunkowy i jest uwarunkowane: podatnością komórek nabłonkowych na wystąpienie proliferacji zależnej od HPV, zaburzeniami funkcjonowania mechanizmów odpowiedzi immunologicznej typu komórkowego, uszkodzeniem tkanek, działaniem hormonów sterydowych i współistnieniem infekcji wywołanych innymi wirusami $[75,77]$.

\section{Epidemiologia RRP}

W latach 1970-1990 współczynnik zachorowalności kształtował się na poziomie 0,6-4,3 nowych przypadków rocznie na 100 tysięcy dzieci. Był niższy w Europie w stosunku do innych kontynentów [78]. Według danych Centers for Disease Control and Prevention oraz Recurrent Respiratory Papillomatosis Task Force wskaźnik zachorowalności w Europie obniżył się do 0,24 w 2009 roku [78]. W tym samym okresie średni współczynnik zachorowalności w USA wynosił 0,73 i wahał się dla poszczególnych stanów w granicach 0,12 do 2,13 [79]. Rozrzut wyników jest uwarunkowany wieloczynnikowo: zróżnicowaniem geograficznym, różnymi szacunkami zachorowalności w poszczególnych regionach świata, rozproszoną „,dystrybucją" określonych typów wirusa w poszczególnych populacjach. Ten sam wskaźnik w Tajlandii jest szacowany na 2,8 i pozostaje 12 razy wyższy niż w krajach europejskich, podczas gdy w Afryce wynosi 4,3. W USA rozpoznaje się niespełna 1000 nowych zachorowań na 305 milionów ludzi, w 62-milionowej populacji Wielkiej Brytanii 103 pacjentów pozostaje pod opieką wszystkich ośrodków laryngologicznych [79].

\section{Czynniki ryzyka zachorowania}

Potwierdzenie obecności kłykcin kończystych lub płaskich $\mathrm{w}$ obrębie dróg rodnych u matki w momencie porodu siłami natury podnosi ryzyko wystąpienia RRP nawet 231 razy w stosunku do braku jawnych klinicznie cech infekcji [80]. Możliwość wystąpienia RRP u dziecka urodzonego w takich warunkach wynosi jednak mniej niż 1\% [81]. Powszechnie akceptowana jest teoria opisująca wertykalną drogę zakażenia płodu w trakcie pasażu przez zainfekowany kanał rodny [82, 83] - szacunkowe ryzyko przeniesienia zakażenia HPV z matki na dziecko $\mathrm{w}$ trakcie pasażu wynosi 1:80-400 porodów [84]. Wykazano, że dzieci z RRP wyjątkowo pochodzą z porodu dokonanego drogą cięcia cesarskiego [75]. Niemniej rola cięcia cesarskiego jako środka zapobiegającego transmisji HPV wydaje się być ograniczona.

Odmiennie wygląda sytuacja w przypadku zakażenia wirusami o wysokim potencjale onkogennym. W przypadku kiedy u matki w obrębie szyjki macicy stwierdzano zakażenie HPV 16, obecność tego samego typu wirusa wykazywano w wymazach z górnych dróg oddechowych aż u 50\% noworodków. Badania kliniczne wskazują również na pozapłciową drogę przenoszenia zakażenia potwierdzoną u noworodków, niemowląt i małych dzieci, których matki nie miały zakażenia HPV. Ponadto wykrywanie wirusów Papilloma w płynie owodniowym i krwi pępowinowej oraz w komórkach syncytiotrofoblastu u ciężarnych z aktywnym zakażeniem w obrębie szyjki macicy sugeruje możliwość zakażenia wewnątrzmacicznego. Konsekwencją zakażenia okołoporodowego może być rozwój RRP, który następuje po kilkumiesięcznym, a czasami nawet wieloletnim okresie utajenia wirusa w makroskopowo prawidłowych tkankach $[82,84]$.

\section{Obraz kliniczny RRP}

W przebiegu RRP obserwuje się dwufazowy szczyt zachorowań: między 2. a 5. rokiem życia, charakterystyczny dla dziecięcej postaci klinicznej choroby, i pojedyncze przypadki w okresie poprzedzającym pokwitanie [85-87]. Szczególnie niekorzystne jest rokowanie przy zachorowaniu w pierwszym lub drugim roku życia [86], a zwłaszcza przed ukończeniem szóstego miesiąca, w tej grupie śmiertelność osiąga $100 \%$ [88, 89]. Wczesne zachorowanie jest skorelowane z HPV 11, implikuje częste nawroty, konieczność powtarzania zabiegów endoskopowych udrażniających drogi oddechowe minimum czterokrotnie w roku. Wzrasta prawdopodobieństwo rozsiewu zmian do tchawicy, oskrzeli i miąższu płuc. Późniejszy początek związany jest z łagodniejszym przebiegiem klinicznym [77, 86, 89, 90]. U pacjentów starszych wykrywany jest częściej HPV 6 . Zmiany są wtedy przeważnie mniej liczne i stosunkowo rzadko wywołują krytyczne zaburzenia drożności dróg oddechowych [86].

\section{Identyfikacja DNA HPV HR jako narzędzie diagnostyczne w przypadkach HNSCC}

\section{Znaczenie oceny pacjenta przed dokonaniem doboru terapii i przystapieniem do leczenia}

Ocena pacjenta z HNSCC o lokalizacji pierwotnej w części ustnej gardła obejmuje diagnostykę molekularną wirusa HPV równolegle z klasycznym badaniem histologicznym. Pozwala to na: 1) uzyskanie pełnego rozpoznania, 2) wydzielenie podtypu raków HPV zależnych, 3) poinformowanie pacjenta o istocie choroby i rokowaniu, 4) zaplanowanie dalszej terapii [21, 91-93]. W świetle aktualnej wiedzy (ASCO 2012), raki HPV-zależne podlegają innemu modelowi postępowania w związku z istotnie lepszą odpowiedzią na radiochemioterapię i lepszym rokowaniem ich leczenie uległo deintensyfikacji, tj. zmniejszono dawki promieniowania. Taka strategia pozwala uniknąć powikłań lub zmniejszyć działania uboczne przy równie wysokich odsetkach wyleczeń [17, 94, 95]. Precyzyjne rozpoznanie i podział na dwie odrębne ścieżki terapeutyczne ma zasadnicze znaczenie dla porównania dotychczasowych wyników leczenia poszczególnych ramion 
prób klinicznych II fazy i stanowi punkt wyjścia dla zaprojektowania badań III fazy. Jest to potencjalnie krok w kierunku indywidualizowania terapii $[71,96]$. Deintensyfikacja leczenia i efektywność stosowania terapii celowanych pozostaje przedmiotem debaty [97, 98].

\section{Ocena tkanki guza pochodzącej z wycinka}

\section{Ocena histopatologiczna}

W rozwoju biologicznie adekwatnej klasyfikacji, opartej na parametrach morfologicznych i markerach molekularnych, ważna jest rola patologa oraz rosnąca rola diagnosty laboratoryjnego (jako osoby wykonującej część oznaczeń, które następnie są integrowane $\mathrm{z}$ rozpoznaniem lekarskim). Uregulowanie minimów diagnostycznych dla pełnej diagnozy HPV-zależnych HNSCC jest zadaniem pilnym, ale ciągle nierozstrzygniętym. Ze względu na szczególną rolę typu HPV 16 wskazane jest wprowadzanie badań mających na celu potwierdzenie zakażenia, zwłaszcza w OPC. Określenie statusu HPV w przypadku nowotworów HPV-zależnych może zostać przeprowadzone z zastosowaniem jednego lub kombinacji kilku testów.

Zgodnie $\mathrm{z}$ wytycznymi College of American Pathologists (Tab. I i II) w badaniu histopatologicznym dodano wymaganie oznaczenia $p 16^{I N K 4 A}$ i zmieniono zasady oceny występowania HPV. Zmiany cytowane są z fragmentów protokołu opracowania materiału diagnostycznego:

Ocena tkanki guza technikami biologii molekularnej Ogólna zasada stosowana w identyfikacji i genotypowaniu HPV opiera się na wykrywaniu hybryd, które tworzą swoiste sondy DNA lub RNA z komplementarnymi fragmentami DNA badanej próbki tkankowej. Różnice swoistości i czułości poszczególnych metod związane są ze sposobem przygotowania materiału (wykrywanie bezpośrednie lub konieczność powielania wirusowego DNA) oraz technikami wykrywania otrzymanych hybryd. Czułość badania oznacza najmniejszą liczbę kopii wirusowego DNA w komórce, jaką można wykryć daną techniką.

Technika PCR (polimerase chain reaction - łańcuchowa reakcja polimerazy) opiera się na powielaniu badanego fragmentu DNA. Pozwala na wykrycie obecności wirusa występującego w jednej kopii na dziesięć komórek. Umożliwia też jednoczesne oznaczanie wielu typów HPV. Ceną wysokiej czułości jest wrażliwość na zanieczyszczenie badanego mate-
Tabela I - Wytyczne dotyczące uzupelnienia protokołu badania histopatologicznego

Badania dodatkowe (wymagane) [p16, HPV] (wybierz każde

z występujących):

1. $p 16$ : dodatnie lub ujemne

2. Human papillomavirus (HPV):

a. hybrydyzacja in situ (ISH). Typ (określ)

dodatni: morfologia: punktowo, rozlana, mieszana ujemne: pośredni (wyjaśnij)

b. łańcuchowa reakcja polimerazy (PCR). Typ (określ): dodatni/ ujemny

riału „obcym” DNA pochodzącym spoza próbki. Najpowszechniej do detekcji DNA HPV HR w reakcji PCR stosowane są startery GP5+/6+. Zastosowanie znajdują również komercyjnie dostępne testy genotypujące HPV oraz metoda sekwencjonowania. Badanie to może być przeprowadzone z świeżego i mrożonego materiału tkankowego oraz skrawków parafinowych i wymazów. Najlepszy materiał to badań stanowią świeże lub mrożone skrawki tkankowe. Wybór materiału do badania wymaga uprzedniego ustalenia $\mathrm{z}$ laboratorium.

Technika Southern-blot czy Dot-blot ma wysoką czułość (w zakresie już od 0,1 do 1 kopii DNA na komórkę) oraz specyficzność. Opiera się na hybrydyzacji wirusowego DNA z komplementarną sondą i umożliwia zidentyfikowanie całego genomu wirusa. Wymaga natomiast znacznej ilości materiału do analizy, jest skomplikowana i czasochłonna.

Odrębną grupę badań opartych na technice PCR stanowi analiza transkryptów wirusowych genów E6/E7 $\mathrm{z}$ zastosowaniem RT-PCR (reverse transcriptase PCR). PCR z odwrotną transkryptazą należy do najbardziej czułych metod wykrywania niewielkich ilości cząsteczki mRNA w próbce. Dzięki RT-PCR możliwe jest określenie poziomu ekspresji wirusa. Badanie wirusowych onkogenów E6 i E7 przez niektórych autorów jest uznawane za ,złoty standard” z uwagi na fakt, że oddziałują one z komórkowymi białkami p53 i pRB. Wirusowe białko E7 wiąże się z pRB, co prowadzi do uwolnienia czynnika E2F z kompleksu pRB:E2F i ekspresji białek niezbędnych do replikacji DNA, natomiast białko wirusowe E6 oddziałuje z kolei z białkiem p53. Wykazano, że nadekspresja genów wirusowych E6 i E7 jest niezbędna do wejścia komórki na drogę transformacji nowotworowej.

Tabela II - Zalecenia oceny DNA HPV w rakach plaskonablonkowych gardla środkowego w oparciu o ocenę profilu ekspresji $p 16^{\mathrm{INK} 4 \mathrm{~A}} \mathrm{w}$ badaniu immunohistochemicznym

\begin{tabular}{|c|c|c|}
\hline Morfologia raka & $p 16^{\mathrm{INK} 4 \mathrm{~A}}$ & $\begin{array}{l}\text { Wymagane badanie potwierdzające } \\
\text { obecność DNA wirusa HPV }\end{array}$ \\
\hline $\begin{array}{l}\text { Nierogowaciejące lub w przeważającej } \\
\text { części nierogowaciejące }\end{array}$ & $\begin{array}{l}\text { Reakcja silna i rozlana } \\
\text { (cytoplazmatyczna i jądrowa, tj. >70\%) }\end{array}$ & Nie \\
\hline $\begin{array}{l}\text { Nierogowaciejące lub w przeważającej } \\
\text { części nierogowaciejące }\end{array}$ & $\begin{array}{l}\text { Reakcja ujemna lub } \\
\text { dodatnia tylko ogniskowo }\end{array}$ & Tak \\
\hline Rogowaciejący & $\begin{array}{l}\text { Reakcja silna i rozlana } \\
\text { (cytoplazmatyczna i jądrowa, tj. >70\%) }\end{array}$ & Tak \\
\hline Rogowaciejący & Reakcja ujemna lub dodatnia tylko ogniskowo & Nie \\
\hline
\end{tabular}


Badanie transkryptów wirusowych może być przeprowadzone z świeżego i mrożonego materiału tkankowego. Z uwagi na zazwyczaj bardzo słabą jakość RNA ze skrawków parafinowych nie rekomenduje się stosowania tego materiału rutynowo.

Techniką, która umożliwia analizę transkryptów wirusowych bezpośrednio w badanej tkance i nie wymaga izolacji oraz amplifikacji RNA, jest hybrydyzacja in situ (ISH). Zastosowanie sond RNA dla HPV E6/E7 umożliwia analizę integracji oraz transkrypcyjnej aktywności wirusa w badanym materiale. Analiza transkryptów wirusowych (mRNA HPV) z zastosowaniem metod PCR lub ich bezpośrednia wizualizacja w tkance metodą ISH pozwalają na rozróżnienie infekcji przetrwałej od przejściowej, co może stanowić cenne uzupełnienie prowadzonej diagnostyki.

Inną metodę detekcji DNA HPV stanowi fluorescencyjna hybrydyzacja in situ (FISH). Metoda ta jest skomplikowana i wymaga zastosowania mikroskopu fluorescencyjnego. Dodatkowe utrudnienie stanowi nieczytelny obraz wynikający np. $z$ dużej ilości sygnałów lub integracji HPV $\mathrm{z}$ genomem gospodarza. Badanie to odznacza się wysoką swoistością, lecz stosunkowo niską czułością, tj. 85-88\%. Do badań mogą zostać wykorzystane tkankowe skrawki parafinowe.

Metodą pośredniej analizy transformacji nowotworowej komórki z udziałem wirusa HPV jest immunohistochemiczne badanie ekspresji $p 16^{\mathrm{INK} 4 \mathrm{~A}}$. Uważa się, że nadekspresja $p 16^{\mathrm{INK} 4 \mathrm{~A}}$ jest wynikiem wiązania białka pRB przez wirusowe białko E7 oraz oddziaływania wirusowego białka E6 z białkiem p53 na wskutek ujemnego sprzężenia zwrotnego. Wielu autorów dowodzi, że badanie to ma bardzo wysoką czułość (90-100\%), ale niską (ok. 80\%) swoistość, co może przekładać się na duży odsetek (20\%) wyników fałszywie pozytywnych.

Podsumowując, u chorych z OPC bezwzględnie powinna zostać wykonana ocena DNA HPV HR. Badanie to umożliwia identyfikację wirusa, ale nie pozwala ocenić jego aktywności transkrypcyjnej. U pacjentów DNA HPV HR (+) należy rozważyć genotypowanie wirusa z szczególnym uwzględnieniem typów HPV 16 i 18 . Badanie ekspresji p16 ${ }^{\text {INK4A }}$ $\mathrm{w}$ połączeniu z badaniem DNA HPV zwiększa czułość badania. Badanie mRNA HPV może stanowić cenne uzupełnienie, lecz nie jest bezwzględnie wymagane. Umożliwia wykrycie zintegrowanej formy wirusa. Spośród wielu metod analizy HPV dla tkanki guza najczęściej stosuje się: oznaczanie $p 16^{\mathrm{INK} 4 \mathrm{~A}}$ metodą immunohistochemiczną (IH), hybrydyzację in situ (ISH) i PCR. Dla węzłów chłonnych (materiał diagnostyczny pobrany różnymi technikami) zaleca się wykonanie badań immunohistochemicznych w celu oceny HPV $16 \mathrm{i} / \mathrm{lub} p 16^{\mathrm{INK} 4 \mathrm{~A}}$.

Próba ustalenia algorytmu diagnostycznego

Autorzy podejmujący próbę stworzenia algorytmu diagnostycznego uważają, że rozpoznanie HPV-zależnego HNSCC powinno być ustalane na podstawie kombinacji dwóch parametrów: cech guza (HPV DNA lub p16) i badania HPV E6/7 [99, 100]. Metoda łączona detekcji DNA HPV z wykorzystaniem metody PCR i starterów reakcji GP5+/6+ oraz immunohistochemicznej analizy ekspresji $p 16^{I N K 4 A}$ ma czułość 96-97\% i swoistość 94-98\%.. Silny związek pomiędzy zaklasyfikowaniem guza jako HPV-zależnego a rokowaniem (ocenianym na podstawie odsetków przeżyć zależnych od choroby) jest potwierdzony, wówczas gdy stosujemy oba parametry łącznie. Co więcej, pacjenci seronegatywni dla przeciwciał E6/E7 mają istotnie wyższe ryzyko zgonu pomimo nadekspresji $p 16^{\text {INK4A }}$, ponieważ ten parametr może być modulowany przez inne czynniki sprawcze, niezależne od HPV [101].

Jednym z podstawowych kryteriów doboru testu jest efektywność kosztów. Wykonanie jednego badania w USA to koszt: $p 16^{\mathrm{INK} 4 \mathrm{~A}} \mathrm{IH}-25 \$$, HPV DNA PCR z genotypowaniem 400\$, HPV DNA ISH - 55\$, HPV RNA ISH - 157\$, HPV RT-PCR dla E6,E7 - 150\$ [93].

Zgodnie z wytycznymi National Comprehensive Cancer Network 2011, dla raków głowy i szyi pojedynczym testem zalecanym dla OPC w celu określenia rokowania jest p16 ${ }^{\text {INK4A }}$ IHC. Ma udokumentowaną wartość, jest powszechnie dostępny, niedrogi, łatwy do interpretacji, $z$ jasnymi wytycznymi co do punktu odcięcia [93]. W celu potwierdzenia wartości metody otwarto dwa badania kliniczne RTOG-1016 i RTOG-0920.

\section{Ocena wymazu szczoteczkowego}

Badanie to należy rozważyć w przypadku braku dostępności materiału tkankowego. Ocenę infekcji HPV należy dokonać poprzez badanie DNA HPV HR. Z uwagi na bardzo małą ilość materiału komórkowego, jaką można uzyskać z wymazu, oraz brak komercyjnie dostępnych testów zwalidowanych na materiał pochodzący $\mathrm{z}$ wymazów laryngologicznych badanie to może nie być dostępne.

Propozycja schematu postępowania u chorych z rakiem ustnej części gardła

(Ryc. 1)

Standardy jakości diagnostyki HPV, jej wartości informacyjnej oraz laboratoryjnej interpretacji i autoryzacji wyniku badań laboratoryjnych

Pobieranie i transport materiału do badań DNA HPV

Formularz zlecenia badania, szczegółowe instrukcje dotyczące pobierania, przechowywania i transportu próbek dostarcza laboratorium wykonujące badanie DNA HPV.

Pobieranie wymazu

Wymaz powinien zostać pobrany szczoteczką lub nylonową wymazówką z miejsc podejrzanych i zawieszony w podłożu transportowym walidowanym przez laboratorium. Rekomenduje się zabezpieczenie materiału w buforze do płynnej cytologii i testu HPV. Ilość medium transportowego nie powinna przekraczać 1,5-5 ml. Tak pobrane komórki są bardzo dobrze zakonserwowane, co umożliwia ich transportowanie w temperaturze pokojowej $\left(15-30^{\circ} \mathrm{C}\right)$ bez negatywnego wpływu na wynik badania. Zamknięte probówki z materiałem komórkowym zawieszonym w płynnym podłożu transportowym powinny być przechowywane zgodnie z wytycznymi producenta. System pobierania i transportu musi zawsze być walidowany ze stosowanym testem diagnostycznym celem uniknięcia błędów przedanalitycznych i zapewnienia wiarygodnych wyników. 


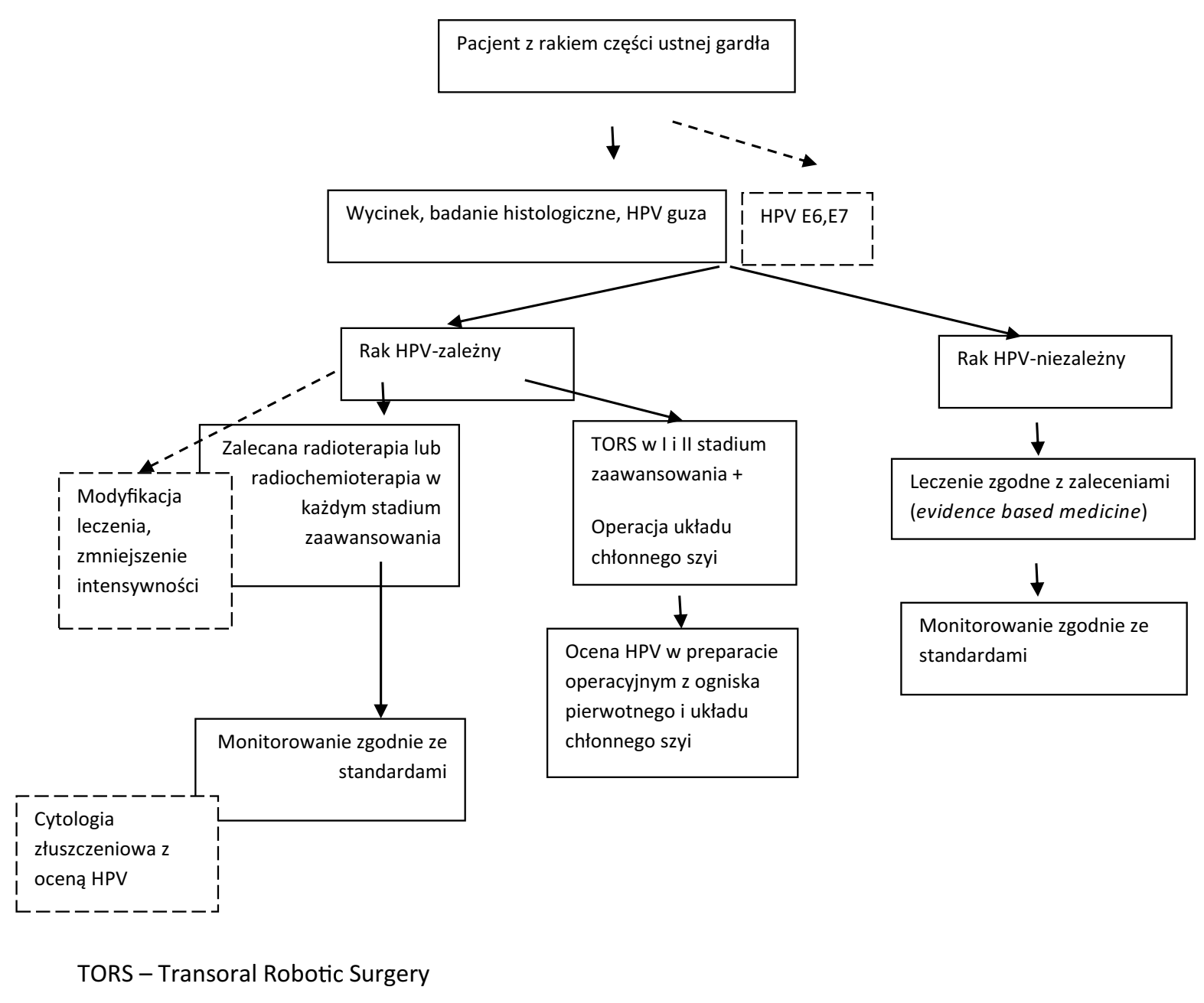

Ryc. 1 - Schemat postępowania z pacjentem $\mathrm{z}$ rakiem części ustnej gardła

Probówki z wymazempowinny zawierać następujące dane pacjenta: imię, nazwisko, PESEL oraz datę pobrania lub kod paskowy.

\section{Materiał tkankowy}

Fragmenty tkanek do badania DNA HPV z zastosowaniem metody PCR mogą zostać zamrożone lub zawieszone w probówce $\mathrm{z}$ podłożem do płynnej cytologii i testu HPV, a następnie zabezpieczone w lodówce (temp. $2-8^{\circ} \mathrm{C}$ ).

Transport materiału do badań laboratoryjnych

Wymazy lub świeże fragmenty tkankowe zabezpieczone w podłożu do płynnej cytologii i testu HPV mogą być transportowane $\mathrm{w}$ temperaturze pokojowej. Transport $\mathrm{w}$ temp. od $2-8{ }^{\circ} \mathrm{C}$ stanowi dodatkowe zabezpieczenie. W przypadku transportu materiału mrożonego nie należy dopuścić do jego rozmrożenia i ponownego zamrażania. Materiał jest transportowany w zamkniętych probówkach lub pojemnikach, w zamkniętym opakowaniu zbiorczym, oznakowanym „materiał zakaźny”.

\section{Metody badawcze}

Laboratorium stosuje metody badawcze, które odpowiadają aktualnej wiedzy medycznej i zostały przez nie odpowiednio zwalidowane.

\section{Wyniki fałszywie negatywne}

Zbyt mała ilość komórek pobranych do badania lub nieprawidłowe przechowywanie i warunki transportu próbki oraz błędy analityczne mogą prowadzić do uzyskania wyniku fałszywie negatywnego. W molekularnej diagnostyce DNA HPV należy stosować testy mające wewnętrzną kontrolę komórkową (np. amplifikacja i detekcja genu $\beta$-globiny), która stanowi ocenę poprawności: pobrania wymazu, przeprowadzenia procesu ekstrakcji oraz amplifikacji DNA i zabezpiecza przed wydaniem wyniku fałszywie ujemnego.

Wyniki fałszywie pozytywne

Wysoka czułość metod molekularnych wykrywających DNA HPV niesie ze sobą ryzyko wyników fałszywie pozytywnych 
z powodu zanieczyszczenia próbki badanej przez niewielkie ilości DNA innych pacjentów. Stąd zaleca się stosowanie testów zawierających enzymatyczne zabezpieczenia przed wydaniem wyniku fałszywie pozytywnego w następstwie kontaminacji (np. UNG i dUTP).

\section{Przedstawianie i wydawanie wyników badań DNA HPV}

Formularz sprawozdania $\mathrm{z}$ badania DNA HPV prowadzony jest zgodnie z rozporządzeniem Ministra Zdrowia i autoryzowany przez diagnostę laboratoryjnego mającego tytuł specjalisty z laboratoryjnej genetyki medycznej lub mikrobiologii medycznej i legitymujących się co najmniej 2-letnim doświadczeniem w diagnostyce molekularnej. Formularz sprawozdania $\mathrm{z}$ badania laboratoryjnego może być przekazany w formie elektronicznej z zachowaniem wymagań prawnych.

\section{Wymagania dotyczące laboratorium}

Laboratorium musi spełniać standardy jakości podane w rozporządzeniu Ministra Zdrowia w sprawie standardów jakości dla medycznych laboratoriów diagnostycznych i mikrobiologicznych, w szczególności:

- opracowuje, wdraża i stosuje procedury przyjmowania, rejestrowania i laboratoryjnego oznakowywania materiału do badań oraz udostępnia je zleceniodawcom, którzy potwierdzają zapoznanie się z tymi procedurami,

- prowadzi wewnętrzną kontrolę jakości badań i uczestniczy w zewnętrznej kontroli jakości zgodnie $\mathrm{z}$ rozporządzeniem Ministra Zdrowia [102-104].

\section{UWAGA!}

Badanie laboratoryjne wykonane wg wskazań i zasad przytoczonych powyżej powinno zawsze być korelowane $\mathrm{z}$ rutynowo wykonywanym badaniem histopatologicznym ocenianym przez lekarza specjalistę w zakresie patomorfologii. Ograniczenie diagnostyki do wyniku oznaczenia diagnostyki HPV nie rozstrzyga bowiem o wyniku, czy zmiana ma charakter łagodny (i jest jedynie rozrostowa), czy jest rakiem in situ, czy rakiem inwazyjnym.

\section{Identyfikacja DNA HPV LR w przypadkach RRP}

Prowadzone dotychczas badania w populacjach dziecięcych mają charakter nieusystematyzowany, wyłącznie poznawczy, odbywają się według nieujednoliconych schematów i są prowadzone różnymi technikami [105]. Czynniki wpływające na duże rozbieżności uzyskiwanych wyników są związane z czułością metod badawczych stosowanych do identyfikacji DNA HPV LR [106].

Poniżej w formie tabelarycznej podsumowano specyficzne właściwości charakteryzujące wybrane techniki biologii molekularnej, wykorzystywane powszechnie do identyfikacji materiału genetycznego wirusów brodawczaka ludzkiego w próbkach tkankowych (Tab. III).

\section{Podsumowanie}

\section{Stan wiedzy i kierunki badań w HPV HR}

1. Metaanalizy prowadzone w literaturze bezsprzecznie dowodzą roli HPV w rozwoju HNSCC, zwłaszcza raków ustnej części gardła.

2. Trendy zapadalności jednoznacznie wskazują na wzrost liczby przypadków raków HPV-zależnych w zakresie głowy i szyi, przede wszystkim o lokalizacji w części ustnej gardła.

3. HPV jako cecha biologiczna raka jest udokumentowanym korzystnym czynnikiem rokowniczym dla raków gardła,

Tabela III - Porównanie technik biologii molekularnej stosowanych do wykrywania sekwencji DNA ludzkiego wirusa Papilloma

\begin{tabular}{|c|c|c|c|c|}
\hline \multirow[t]{2}{*}{ Nazwa metody } & \multirow{2}{*}{$\begin{array}{c}\text { Wykorzystywany } \\
\text { materiał } \\
\text { biologiczny }\end{array}$} & \multirow{2}{*}{$\begin{array}{l}\text { Czułość metody } \\
\text { (minimalna ilość kopii } \\
\text { HPV wykrywana } \\
\text { w komórce) }\end{array}$} & \multicolumn{2}{|c|}{ Charakterystyka metody } \\
\hline & & & Zalety & Wady \\
\hline $\begin{array}{l}\text { FISH Hybrydyzacja in situ } \\
\text { z użyciem filtrów }\end{array}$ & Homogenat komórkowy & $10-100$ & $\begin{array}{l}\text { Szybkość } \\
\text { przeprowadzenia } \\
\text { badania }\end{array}$ & $\begin{array}{l}\text { Niska czułość, niewielka } \\
\text { specyficzność }\end{array}$ \\
\hline $\begin{array}{l}\text { NISH Nieizotopowa } \\
\text { hybrydyzacja in situ }\end{array}$ & $\begin{array}{l}\text { Preparaty histologiczne } \\
\text { i cytologiczne }\end{array}$ & 20 & $\begin{array}{l}\text { Zachowanie cech } \\
\text { morfologicznych badanej } \\
\text { tkanki z możliwością } \\
\text { oceny komórkowej } \\
\text { lokalizacji DNA }\end{array}$ & $\begin{array}{l}\text { Niska czułość, znaczna } \\
\text { pracochłonność }\end{array}$ \\
\hline Southern Blot & Izolowane DNA & $\begin{array}{l}\text { 0,1-1 (ilość badanego } \\
\text { DNA 5-10 } \mu \mathrm{g} \text { ) }\end{array}$ & Wysoka specyficzność & $\begin{array}{l}\text { Potrzebna duża ilość } \\
\text { materiału biologicznego, } \\
\text { znaczna pracochłonność }\end{array}$ \\
\hline Dot Blot & Izolowane DNA & $1-10$ & Wysoka specyficzność & Znaczna pracochłonność \\
\hline$\overline{\mathrm{PCR}}$ & $\begin{array}{l}\text { Izolowane DNA, } \\
\text { preparaty histologiczne, } \\
\text { homogenaty tkankowe }\end{array}$ & $\begin{array}{l}1 \text { kopia w całej } \\
\text { analizowanej próbce }\end{array}$ & $\begin{array}{l}\text { Wysoka czułość, szybkość } \\
\text { przeprowadzenia badania, } \\
\text { możliwość jednoczasowego } \\
\text { wykrywania wielu typów } \\
\text { wirusa }\end{array}$ & $\begin{array}{l}\text { Niebezpieczeństwo } \\
\text { kontaminacji badanego } \\
\text { materiału „obcym” DNA }\end{array}$ \\
\hline
\end{tabular}


niejasna pozostaje rola HPV w innych lokalizacjach pierwotnych HNSCC.

4. Opracowano i ujednolicono metodykę wykrywania HPV $\mathrm{u}$ chorych $\mathrm{z}$ rakami HNSCC. Rutynowe badanie raków jamy ustnej i ustnej części gardła pod kątem statusu HPV jest rekomendowane jako standard.

5. Nie wyselekcjonowano dotychczas grup ryzyka i nie podjęto badań przesiewowych w celu wczesnej diagnostyki stanów przedrakowych jamy ustnej i ustnej części gardła w powiązaniu z zakażeniem wirusem HPV.

EUROGIN 2011 [2] - mapa drogowa prewencji i leczenia chorób HPV zależnych jako przyszłe kierunki badań wskazuje:

1. Ocenę zakażenia HPV w HNSCC (poza lokalizacją w części ustnej gardła).

2. Molekularną ocenę poprawy wyników leczenia radiochemioterapią HPV-zależnych HNSCC.

3. Ocenę populacyjnej częstości występowania infekcji HPV jamy ustnej i dystrybucję HPV w poszczególnych częściach tej lokalizacji anatomicznej.

4. Badanie naturalnej historii infekcji HPV jamy ustnej.

5. Efektywność szczepień przeciwko HPV w prewencji zakażeń HPV 16 jamy ustnej.

6. Potencjalne zastosowanie testów HPV w badaniach przesiewowych zakażeń jamy ustnej.

7. Precyzyjną charakterystykę HPV-dodatnich stanów przedrakowych.

Punkty nieujęte w programie EUROGIN 2011:

1. Zastosowanie poziomu przeciwciał przeciwko HPV do monitorowania pacjentów leczonych $\mathrm{z}$ powodu HPV-zależnych HNSCC; wstępne doniesienia wskazują, że poziomy ekspresji E6 i E7 obniżone w okresie po leczeniu w porównaniu ze stanem wyjściowym mogą być związane $\mathrm{z}$ remisją, a poziomy podwyższone sugerują obecność nowotworu przetrwałego lub wznowy [48, 107, 108].

2. Ocena HPV LR w rakach brodawkowatych krtani; koinfekcja HPV LR może stanowić przyczynek do zmiany wyboru leczenia (rezygnacja z radioterapii na rzecz chirurgii).

\section{Stan wiedzy i kierunki badań w HPV LR}

Dotychczas brak zaleceń dla rutynowej identyfikacji genotypów HPV w przebiegu RRP u dzieci. Zalecenia wg BAPO/ ASPO (British Association of Pediatric Otorhinolaryngology/American Society of Pediatric Otolaryngology) dla oceny udziału poszczególnych typów HPV w przypadkach agresywnego przebiegu RRP:

1. Wystąpienie objawów w dwóch pierwszych latach życia.

2. Częstość nawrotów wymagających udrożnienia dróg oddechowych min cztery razy w roku.

3. Rozprzestrzenianie zmian brodawczakowych poniżej poziomu głośni.

Identyfikacja HPV w błonach śluzowych górnych dróg oddechowych u dzieci bez RRP:

1. Urodzone siłami natury przez matki z klinicznie jawną infekcja HPV w obrębie dróg rodnych.

2. Urodzone przez matki z udokumentowanym zakażeniem wysoko-onkogennymi typami HPV.

3. Ofiary wykorzystania seksualnego.

Podsumowując, pomimo braku ostatecznie ustabilizowanego algorytmu i w pełni zwalidowanych metod badawczych istnieje konieczność oznaczania wirusa HPV w przypadkach, w których wartość tej diagnostyki została udokumentowana, tj. w rakach ustnej części gardła i w wybranych przypadkach brodawczakowatości dróg oddechowych.

\section{Wkład autorów/Author's contribution}

Według kolejności/According to order.

\section{Finansowanie/Financial support}

Nie występuje/None declared.

\section{Konflikt interesu/conflict of interest}

Nie występuje/None declared.

\section{Etyka/Ethics}

Treści przedstawione $\mathrm{w}$ artykule są zgodne $\mathrm{z}$ zasadami Deklaracji Helsińskiej, dyrektywami EU oraz ujednoliconymi wymaganiami dla czasopism biomedycznych.

The work described in this article have been carried out in accordance with The Code of Ethics of the World Medical Association (Declaration of Helsinki) for experiments involving humans; EU Directive 2010/63/EU for animal experiments; Uniform Requirements for manuscripts submitted to Biomedical journals.

\section{PIŚM I E N N I C T W O/REFERENCES}

[1] Goździcka-Józefiak A, Kwaśniewska A. Właściwości onkogenne wirusa brodawczaka ludzkiego. W: Spaczyński M, Kędzia W, Nowak-Markwitz E, reds. Rak szyjki macicy. Profilaktyka, diagnostyka i leczenie. PZWL: 2009. p. 17-30.

[2] Arbyn M, de Sanjosé S, Saraiya M, Sideri M, Palefsky J, Lacey C, et al. EUROGIN 2011 roadmap on prevention and treatment of HPV-related disease. Int J Cancer 2012;131 (9):1969-1982.

[3] Fritz A, Percy C, Jack A, Shanmugaratnam K, Sobin L, et al. International classification of diseases for oncology, 3rd ed., Geneva: World Health Organization; 2000.

[4] Zur Hausen H. Papillomaviruses in human cancers. Proc Assoc Am Physicians 1999;111(6):581-587.

[5] Syrjanen S. Human papillomavirus (HPV) in head and neck cancer. J Clin Virol 2005;32:59-66.

[6] Erdmann J. Recent studies attempt to clarify relationship between oral cancer and human papillomavirus. J Natl Cancer Inst 2003;7(95(9)):638-639.

[7] Nair S, Pillai MR. Human papillomavirus and disease mechanisms: relevance to oral and cervical cancers. Oral Dis 2005;11(6):350-359.

[8] Gillison ML. Current topics in the epidemiology of oral cavity and oropharyngeal cancers. Head Neck 2007;29: 779-792.

[9] Kreimer AR, Clifford GM, Boyle P, Franceschi S. Human papillomavirus types in head and neck squamous cell 
carcinomas worldwide: a systematic review. Cancer Epidemiol Biomarkers Prev 2005;14(2):467-475.

[10] Yang CH, Huang CC, Ko MT, Wei YC, Hwang CF. Human papillomavirus infection and papillary squamous cell carcinoma in the head and neck region. Tumour Biol 2012;12.

[11] Rainsbury JW, Ahmed W, Williams HK, Roberts S, Paleri V, Mehanna H. Prognostic biomarkers of survival in oropharyngeal squamous cell carcinoma: systematic review and meta-analysis. Head Neck 2012;20.

[12] Mork J, Lie AK, Glattre E, Hallmans G, Jellum E, et al. Human papillomavirus infection as a risk factor for squamous-cell carcinoma of the head and neck. N Engl J Med 2001;344:1125-1131.

[13] Hammarstedt L, Lindquist D, Dahlstrand H, Romanitan M, Dahlgren LO, et al. Human papillomavirus as a risk factor for the increase in incidence of tonsillar cancer. Int J Cancer 2006;119:2620-2623.

[14] Hobbs CG, Sterne JA, Bailey M, Heyderman RS, Birchall MA, et al. Human papillomavirus and head and neck cancer: a systematic review and meta-analysis. Clin Otolaryngol 2006;31:259-266.

[15] Ryerson AB, Peters ES, Coughlin SS, Chen VW, Gillison ML, et al. Burden of potentially human papillomavirusassociated cancers of the oropharynx and oral cavity in the US, 1998-2003. Cancer 2008;113:2901-2909.

[16] Smith EM, Rubenstein LM, Haugen TH, Pawlita M, Turek LP. Complex etiology underlies risk and survival in head and neck cancer human papillomavirus, tobacco, and alcohol: a case for multifactor disease. J Oncol 2012;571862.

[17] Chaturvedi AK. Epidemiology and clinical aspects of HPV in head and neck cancers. Head Neck Pathol 2012;6:S16-S24.

[18] Lassen P. The role of Human papillomavirus in head and neck cancer and the impact on radiotherapy outcome. Radiother Oncol 2010;95(3):371-380.

[19] Gillison ML. Human papillomavirus-associated head and neck cancer is a distinct epidemiologic, clinical, and molecular entity. Semin Oncol 2004;31:744-754.

[20] Ang KK, Sturgis EM. Human papillomavirus as a marker of the natural history and response to therapy of head and neck squamous cell carcinoma. Semin Radiat Oncol 2012;22(2):128-142.

[21] Haughey BH, Sinha P. Prognostic factors and survival unique to surgically treated p16+ oropharyngeal cancer. Laryngoscope 2012;122(2):S13-S33.

[22] Ringstrom E, Peters E, Hasegawa M, Posner M, Liu M, et al. Human papillomavirus type 16 and squamous cell carcinoma of the head and neck. Clin Cancer Res 2002;8:3187-3192.

[23] Rosenquist K, Wennerberg J, Schildt EB, Bladstrom A, Goran Hansson B, et al. Oral status, oral infections and some lifestyle factors as risk factors for oral and oropharyngeal squamous cell carcinoma. A populationbased case-control study in southern Sweden. Acta Otolaryngol 2005;125:1327-1336.

[24] D'Souza G, Kreimer AR, Viscidi R, Pawlita M, Fakhry C, et al. Case-control study of human papillomavirus and oropharyngeal cancer. N Engl J Med 2007;356:1944-1956.

[25] D'Souza G, Agrawal Y, Halpern J, Bodison S, Gillison ML. Oral sexual behaviors associated with prevalent oral human papillomavirus infection. J Infect Dis 2009;199:1263-1269.

[26] Sinha P, Logan HL, Mendenhall WM. Human papillomavirus, smoking, and head and neck cancer. Am J Otolaryngol 2012;33(1):130-136.

[27] Rautava J, Syrjänen S. Human papillomavirus infections in the oral mucosa. J Am Dent Assoc 2011;142(8):905-914.

[28] Rietbergen MM, Leemans CR, Bloemena E, Heideman DA, Braakhuis BJ, Hesselink AT, et al. Increasing prevalence rates of HPV attributable oropharyngeal squamous cell carcinomas in the Netherlands as assessed by a validated test algorithm. Int J Cancer 2012 [Epub ahead of print]

[29] Hartwig S, Syrjänen S, Dominiak-Felden G, Brotons M, Castellsagué $\mathrm{X}$. Estimation of the epidemiological burden of human papillomavirus-related cancers and nonmalignant diseases in men in Europe. BMC Cancer 2012;20:12-30.

[30] Mehanna H, Beech T, Nicholson T, El-Hariry I, McConkey C, Paleri V, et al. Prevalence of human papillomavirus in oropharyngeal and nonoropharyngeal head and neck cancer-systematic review and meta-analysis of trends by time and region. Head Neck 2012;20. http://dx.doi.org/ 10.1002/hed.22015 [Epub ahead of print].

[31] Davies L, Welch HG. Epidemiology of head and neck cancer in the United States. Otolaryngol Head Neck Surg 2006;135:451-457.

[32] Rodu B, Cole P. Oral cavity and pharynx-throat cancer in the United States, 1973-2003. Oral Surg Oral Med Oral Pathol Oral Radiol Endod 2007;104:653-658.

[33] Kingsley K, O'Malley S, Ditmyer M, Chino M. Analysis of oral cancer epidemiology in the US reveals state-specific trends: implications for oral cancer prevention. BMC Public Health 2008;8:87.

[34] Szyfter K, Wierzbicka M. Rola wirusa brodawczaka (HPV) w nowotworach głowy i szyi. Postępy w chirurgii głowy i szyi 2008;2:41-50.

[35] Cole L, Polfus L, Peters ES. Examining the incidence of human papillomavirus-associated head and neck cancers by race and ethnicity in the U.S., 1995-2005. PLoS One 2012;7(3).

[36] Shiboski CH, Schmidt BL, Jordan RC. Tongue and tonsil carcinoma: increasing trends in the U.S. population ages 20-44 years. Cancer 2005;103:1843-1849.

[37] Brown LM, Check DP, Devesa SS. Oropharyngeal cancer incidence trends: diminishing racial disparities. Cancer Causes Control 2011;22:753-763.

[38] Patel SC, Carpenter WR, Tyree S, Couch ME, Weissler M, et al. Increasing incidence of oral tongue squamous cell carcinoma in young white women, age 18 to 44 years. J Clin Oncol 2011;29:1488-1494.

[39] Genden EM, Sambur IM, de Almeida JR, Posner M, Rinaldo A, Rodrigo JP. Human papillomavirus and oropharyngeal squamous cell carcinoma: what the clinician should know. Eur Arch Otorhinolaryngol 2012 [Jun 30, Epub ahead of print].

[40] Furniss CS, McClean MD, Smith JF, Bryan J, Nelson HH, et al. Human papillomavirus 16 and head and neck squamous cell carcinoma. Int J Cancer 2007;120:2386-2392.

[41] Joseph AW, D'Souza G. Epidemiology of human papillomavirus-related head and neck cancer. Otolaryngol Clin North Am 2012;45(4):739-764.

[42] Campisi G, Giovannelli L. Controversies surrounding human papilloma virus infection, head \& neck vs oral cancer, implications for prophylaxis and treatment. Head Neck Oncol 2009;30(1):8.

[43] Miller DL, Puricelli MD, Stack MS. Virology and molecular pathogenesis of HPV (human papillomavirus)-associated oropharyngeal squamous cell carcinoma. Biochem J 2012 15;443(2):339-353.

[44] White EA, Kramer RE, Tan MJ, Hayes SD, Harper JW, Howley PM. Comprehensive analysis of host cellular interactions with human papillomavirus e6 proteins identifies new e 6 binding partners and reflects viral diversity. J Virol 2012;86(24):13174-13186.

[45] Silverman DA, Pitman MJ. Current diagnostic and management trends for recurrent respiratory papillomatosis. Curr Opin Otolaryngol Head Neck Surg 2004;12(6):532-537. 
[46] Chaturvedi AK, Engels EA, Anderson WF, Gillison ML. Incidence trends for human papillomavirus-related and -unrelated oral squamous cell carcinomas in the United States. J Clin Oncol 2008;26:612-619.

[47] Hansson BG, Rosenquist K, Antonsson A, Wennerberg J, Schildt EB, Bladström A, et al. Association between infection with human papillomavirus and oral and oropharyngeal squamous cell carcinoma: a populationbased case-control study in southern Sweden. Acta Otolaryngol 2005;125(12):1337-1344.

[48] Ragin CC, Taioli E. Survival of squamous cell carcinoma of the head and neck in relation to human papillomavirus infection: review and meta-analysis. Int J Cancer 2007;121 (8):1813-1820.

[49] Rischin D, Young RJ, Fisher R, Fox SB, Le QT, Peters LJ, et al. Prognostic significance of p16INK4A and human papillomavirus in patients with oropharyngeal cancer treated on TROG 02.02 phase III trial. J Clin Oncol 2010;28 (27):4142-4148.

[50] Syrjänen S, Lodi G, von Bültzingslöwen I, Aliko A, Arduino $P$, Campisi G. Human papillomaviruses in oral carcinoma and oral potentially malignant disorders: a systematic review. Oral Dis 2011;17(1):58-72.

[51] Ribeiro KB, Levi JE, Pawlita M, Koifman S, Matos E, ElufNeto J, et al. Low human papillomavirus prevalence in head and neck cancer: results from two large case-control studies in high-incidence regions. Int J Epidemiol 2011;40 (2):489-502.

[52] Boy S, Van Rensburg EJ, Engelbrecht S, Dreyer L, van Heerden M, van Heerden W. HPV detection in primary intra-oral squamous cell carcinomas-commensal, aetiological agent or contamination? J Oral Pathol Med 2006;35(2):86-90.

[53] Kaminagakura E, Villa LL, Andreoli MA, Sobrinho JS, Vartanian JG, Soares FA, et al. High-risk human papillomavirus in oral squamous cell carcinoma of young patients. Int J Cancer 2012 15;130(8):1726-1732.

[54] van Monsjou HS, van Velthuysen ML, van den Brekel MW, Jordanova ES, Melief CJ, Balm AJ. Human papillomavirus status in young patients with head and neck squamous cell carcinoma. Int J Cancer 2012;130(8):1806-1812.

[55] Duray A, Descamps G, Decaestecker C, Remmelink M, Sirtaine N, Lechien J. Human papillomavirus DNA strongly correlates with a poorer prognosis in oral cavity carcinoma. Laryngoscope 2012;122(7):1558-1565.

[56] de Oliveira DE, Bacchi MM, Macarenco RS, Tagliarini JV, Cordeiro RC, Bacchi CE. Human papillomavirus and Epstein-Barr virus infection, p53 expression, and cellular proliferation in laryngeal carcinoma. Am J Clin Pathol 2006;126(2):284-293.

[57] Baumann JL, Cohen S, Evjen AN, Law JH, Vadivelu S, Attia A, et al. Human papillomavirus in early laryngeal carcinoma. Laryngoscope 2009;119(8):1531-1537.

[58] Morshed K. Association between human papillomavirus infection and laryngeal squamous cell carcinoma. J Med Virol 2010;82(6):1017-1023.

[59] Schlecht NF, Brandwein-Gensler M, Nuovo GJ, Li M, Dunne A, Kawachi N, et al. A comparison of clinically utilized human papillomavirus detection methods in head and neck cancer. Mod Pathol 2011;24(10):1295-1305.

[60] Stephen JK, Chen KM, Shah V, Havard S, Lu M, Schweitzer VP, et al. Human papillomavirus outcomes in an accessto-care laryngeal cancer cohort. Otolaryngol Head Neck Surg 2012;146(5):730-738.

[61] Hoffmann M, Klose N, Gottschlich S, Görögh T, Fazel A, Lohrey C, et al. Detection of human papillomavirus DNA in benign and malignant sinonasal neoplasms. Cancer Lett 2006;239(1):64-70.
[62] Lawson W, Schlecht NF, Brandwein-Gensler M. The role of the human papillomavirus in the pathogenesis of Schneiderian inverted papillomas: an analytic overview of the evidence. Head Neck Pathol 2008;2(2):49-59.

[63] Bishop JA, Guo TW, Smith DF, Wang H, Ogawa T, Pai SI, et al. Human papillomavirus-related carcinomas of the sinonasal tract. Am J Surg Pathol 2012;19.

[64] Bleyer A. Cancer of the oral cavity and pharynx in young females: increasing incidence, role of human papilloma virus, and lack of survival improvement. Semin Oncol 2009;36(5):451-459.

[65] Vageli D, Sourvinos G, Ioannou M, Koukoulis GK, Spandidos DA. High-risk human papillomavirus (HPV) in parotid lesions. Int J Biol Markers 2007;22(4):239-244.

[66] Boland JM, McPhail ED, García JJ, Lewis JE, SchembriWismayer DJ. Detection of human papilloma virus and p16 expression in high-grade adenoid cystic carcinoma of the head and neck. Mod Pathol 2012;25(4):529-536.

[67] Descamps G, Duray A, Rodriguez A, Chantrain G, Depuydt $\mathrm{CE}$, Delvenne $\mathrm{P}$, et al. Detection and quantification of human papillomavirus in benign and malignant parotid lesions. Anticancer Res 2012;32(9):3929-3932.

[68] Morbini P, Dal Bello B, Alberizzi P, Mannarini L, Mevio N, Bertino G, et al. Exfoliated cells of the oral mucosa for HPV typing by SPF10 in head and neck cancer. J Virol Methods 2012;186(1-2):99-103.

[69] Chuang AY, Chuang TC, Chang S, Zhou S, Begum S, Westra $\mathrm{WH}$, et al. Presence of HPV DNA in convalescent salivary rinses is an adverse prognostic marker in head and neck squamous cell carcinoma. Oral Oncol 2008;44(10):915-919.

[70] Fakhry C, Rosenthal BT, Clark DP, Gillison ML. Associations between oral HPV16 infection and cytopathology: evaluation of an oropharyngeal "pap-test equivalent" in high-risk populations. Cancer Prev Res (Phila) 2011;4 (9):1378-1384.

[71] Robinson M, Schache A, Sloan P, Thavaraj S. HPV specific testing: a requirement for oropharyngeal squamous cell carcinoma patients. Head Neck Pathol 2012;6(1):S83-S90.

[72] D'Souza G, Dempsey A. The role of HPV in head and neck cancer and review of the HPV vaccine. Prev Med 2011;53(1): S5-S11.

[73] Sanders AE, Slade GD, Patton LL. National prevalence of oral HPV infection and related risk factors in the U.S. adult population. Oral Dis 2012;18(5):430-441.

[74] Zur Hausen H. Intracellular surveillance of persisting viral infections. Human genital cancer results from deficient cellular control of papillomavirus gene expression. Lancet 1986;2(8505):489-491.

[75] Syrjanen KJ. HPV infections in benign and malignant sinonasal lesions. J Clin Pathol 2003;56(3):174-181.

[76] Fields BN, Knipe DM, Howley PM. Fields virology. Philadelphia: Lippincott-Raven Publishers; 1996.

[77] Szydłowski J, Pucher B, Walkowiak J. Leczenie nawracającej brodawczakowatości układu oddechowego. Fam Med 2010;12:958-960.

[78] Reeves WC, Ruparelia SS, Swanson KI, Derkay CS, Marcus A, Unger ER. National registry for juvenile-onset recurrent respiratory papillomatosis. Arch Otolaryngol Head Neck Surg 2003;129(9):976-982.

[79] Chesson HW, Forhan SE, Gottlieb SL, Markowitz LE. The potential health and economic benefits of preventing recurrent respiratory papillomatosis through quadrivalent human papillomavirus vaccination. Vaccine 2008;26 (35):4513-4518.

[80] Silverberg MJ, Thorsen P, Lindeberg H, Grant LA, Shah KV. Condyloma in pregnancy is strongly suggestive of juvenile-onset recurrent respiratory papillomatosis. Obstet Gynecol 2003;101(4):645-652. 
[81] Silverberg MJ, Thorsen P, Lindeberg H, Ahdieh-Grant L, Shah KV. Clinical course of recurrent respiratory papillomatosis in Danish children. Arch Otolaryngol Head Neck Surg 2004;130(6):711-716.

[82] Gerein V, Soldatski IL, Babkina N, Onufrieva EK, Barysik N, Pfister $\mathrm{H}$. Children and partners of patients with recurrent respiratory papillomatosis have no evidence of the disease during long-term observation. Int J Pediatr Otorhinolaryngol 2006;70(12):2061-2066.

[83] Sinclair KA, Woods CR, Kirse DR, Sinal SH. Anogenital and respiratory tract human papillomavirus infections among children: age, gender and potential transmission through sexual abuse. Pediatrics 2005;116(4):815-825.

[84] Kosko JR, Craig S, Derkay S. Role of cesarean section in prevention of recurrent respiratory papillomatosis - is there one? Int J Pediatr Otorhinolaryngol 1996;35(1): 31-38.

[85] Long YT, Sani A. Recurrent respiratory papillomatosis. Asian J Surg 2003;26(2):112-116.

[86] Buchinsky FJ, Donfack J, Derkay CS, Choi SS, Conley SF, Myer CM, et al. Post: age of child, more than HPV type, is associated with clinical course in recurrent respiratory papillomatosis. PLoS One 2008;3(5):e2263.

[87] Goon P, Sonnex C, Jani P, Stanley M, Sudhoff H. Recurrent respiratory papillomatosis: an overview of current thinking and treatment. Eur Arch Otorhinolaryngol 2008;265(2):147-151.

[88] Silver RD, Rimell FL, Adams GL, Derkay CS, Hester R. Diagnosis and management of pulmonary metastasis from recurrent respiratory papillomatosis. Otolaryngol Head Neck Surg 2003;129(6):622-629.

[89] Loyo M, Pai SI, Netto GJ, Tunkel DE. Aggressive recurrent respiratory papillomatosis in a neonate. Int J Pediatr Totorhinolaryngol 2008;72(6):917-920.

[90] Szyfter W, Wierzbicka M, Jackowska J, Bartochowska A, Banaszewski J. The schedule of intralesional papillomatosis treatment with cidofovir. Otolaryngol Pol 2010;64(2): 98-102.

[91] Isayeva T, Li Y, Maswahu D, Brandwein-Gensler M. Human papillomavirus in non-oropharyngeal head and neck cancers: a systematic literature review. Head Neck Pathol 2012;6(Suppl 1):S104-S120.

[92] O'Rorke MA, Ellison MV, Murray LJ, Moran M, James J, Anderson LA. Human papillomavirus related head and neck cancer survival: a systematic review and metaanalysis. Oral Oncol 2012;48(12):1191-1201.

[93] Lewis Jr JS. p16 Immunohistochemistry as a standalone test for risk stratification in oropharyngeal squamous cell carcinoma. Head Neck Pathol 2012 Jul;6(1): S75-S82.

[94] Loewenthal M, Vitez E, Laban S, Münscher A, Güldenzoph $B$, Knecht R, et al. New aspects of current therapeutic strategies in oropharyngeal carcinoma: highlights of the 2012 ASCO meeting. HNO 2012;60(11):951-956.

[95] Quon H, Richmon JD. Treatment deintensification strategies for HPV-associated head and neck carcinomas. Otolaryngol Clin North Am 2012;45(4):845-861.

[96] Chung CH, Schwartz DL. Impact of HPV-related head and neck cancer in clinical trials: opportunity to translate scientific insight into personalized care. Otolaryngol Clin North Am 2012;45(4):795-806.

[97] Sturgis EM, Ang KK. The epidemic of HPV-associated oropharyngeal cancer is here: is it time to change our treatment paradigms? J Natl Compr Canc Netw 2011;9 (6):665-673.

[98] Psyrri A, Sasaki C, Vassilakopoulou M, Dimitriadis G, Rampias T. Future directions in research, treatment and prevention of HPV-related squamous cell carcinoma of the head and neck. Head Neck Pathol 2012;6:1.

[99] Westra WH. The morphologic profile of HPV-related head and neck squamous carcinoma: implications for diagnosis, prognosis, and clinical management. Head Neck Pathol 2012;6(1):S48-S54.

[100] Deng Z, Hasegawa M, Yamashita Y, Matayoshi S, Kiyuna A, Agena $S$, et al. Prognostic value of human papillomavirus and squamous cell carcinoma antigen in head and neck squamous cell carcinoma. Cancer Sci 2012;103(12): 2127-2134.

[101] Liang C, Marsit CJ, McClean MD, Nelson HH, Christensen BC, Haddad RI, et al. Biomarkers of HPV in head and neck squamous cell carcinoma. Cancer Res 2012;72(19): 5004-5013.

[102] ROZPORZĄDZENIE MINISTRA ZDROWIA1 z dnia 3 marca 2004 r. w sprawie wymagań, jakim powinno odpowiadać medyczne laboratorium diagnostyczne.

[103] ROZPORZNDZENIE MINISTRA ZDROWIA z dnia 21 stycznia 2009 r. zmieniające rozporządzenie w sprawie standardów jakości dla medycznych laboratoriów diagnostycznych i mikrobiologicznych.

[104] ROZPORZĄDZENIE MINISTRA ZDROWIA z dnia 12 stycznia 2011 r. w sprawie wymagań zasadniczych oraz procedur oceny zgodności wyrobów medycznych do diagnostyki in vitro.

[105] Wierzbicka M, Jackowska J, Bartochowska A, Józefiak A, Szyfter W, Kędzia W. Effectiveness of cidofovir intralesional treatment in recurrent respiratory papillomatosis. Eur Arch Otorhinolaryngol 2011;268(9):1305-1311.

[106] Di Lonardo A, Marcante ML, Poggiali F, Venuti A. HPV 16 E7 antibody levels in cervical cancer patients: before and after treatment. J Med Virol 1998;54:192-195.

[107] Li W, Thompson CH, O'Brien CJ, McNeil EB, Scolyer RA, Cossart YE, et al. Human papillomavirus positivity predicts favourable outcome for squamous carcinoma of the tonsil. Int J Cancer 2003;106:553-558. 